\title{
Taxonomy, ecology, and conservation status of Philippine Rafflesia (Rafflesiaceae)
}

\author{
J.F. Barcelona ${ }^{1}$, P.B. Pelser ${ }^{2}$, D.S. Balete ${ }^{3,4}$, L.L. Co ${ }^{3,5}$
}

Key words

conservation

ecology

Philippines

Rafflesia

Rafflesiaceae

taxonomy

\begin{abstract}
The number of Rafflesia species (Rafflesiaceae) reported for the Philippines has grown explosively from two before 2002 to ten or eleven presently. We present an overview of the current knowledge of Philippine Rafflesia by providing a comprehensive account of all the recognized species with their taxonomy, distribution and ecology, plus a key and photographs to aid in identification. Their conservation status and that of the rain forest habitats they require is discussed.
\end{abstract}

Published on 30 October 2009

\section{INTRODUCTION}

Rafflesia R.Br. (Rafflesiaceae) is a genus of parasitic plants growing in the forested lowlands and low to mid-elevation montane forests of Thailand, Peninsular Malaysia, Sumatra, Java, Borneo and the Philippines. The plants entirely lack leaves, chlorophyll, separate stems, and roots, and are therefore completely dependent on their host plants for water and nutrients. The hosts of Rafflesia are species of the liana genus Tetrastigma Planch. (Vitaceae; Plate 1). The parasitic plants live inside the roots and stems of their host and only their flowers emerge. The flowers of some Rafflesia are the largest of all flowering plants, reaching up to $1.5 \mathrm{~m}$ diam in $R$. arnoldi R.Br. (Nais 2001). Although the flowers are typically unisexual, occasionally bisexual flowers are formed (e.g., R. baletei Barcelona \& Cajano). Carrion flies (e.g., Calliphora, Chrysomya, Lucilla, Sarcophaga; Plate 3e; Beaman et al. 1988, Bänzinger 1991, Nais 2001) seem to be the main pollinators of Rafflesia and, at least in some species (notably $R$. schadenbergiana and $R$. speciosa), the flies are attracted by the fetid smell emitted by the flower (Bänzinger 1991). However, hardly any additional details are known about the reproductive biology of Rafflesia. For example, although small mammals have been mentioned as possible dispersal agents (Meijer 1985, Anonymous 1992, Nais 2001), the precise dispersal mechanisms of Rafflesia seeds are all speculative. Furthermore, the host infection process is yet another of Rafflesia's mysteries.

Recent molecular phylogenetic studies have shown that Rafflesia and the other two genera in Rafflesiaceae (Rhizanthes Dumort. and Sapria Griff.) form a well-supported clade nested within Euphorbiaceae s.l. (Davis et al. 2007). This finding may seem surprising at first, because obvious morphological

\footnotetext{
Philippine National Herbarium, Botany Division, National Museum of the Philippines, P. Burgos St., P.O. Box 2659, Manila, The Philippines.

2 University of Canterbury, School of Biological Sciences, Private Bag 4800, Christchurch, New Zealand.

${ }^{3}$ Institute of Biology, College of Science, University of the Philippines, Diliman, Quezon City 1101, The Philippines.

${ }^{4}$ Field Museum of Natural History, Department of Zoology, 1400 South Lake Shore Drive, Chicago IL 60605, USA.

${ }^{5}$ Conservation International-Philippines, 6 Maalalahanin St., Teacher's Village, Diliman, Quezon City 1101, The Philippines.
}

synapomorphies with Euphorbiaceae are wanting, but it is, in retrospect, not completely unexpected considering Rafflesia's highly specialized life form and the incredible morphological diversity of Euphorbiaceae s.I. Despite the current strong interest in the evolutionary history of Rafflesia, species-level phylogenetic relationships are currently unknown.

Until recently, the centre of species diversity of Rafflesia was thought to be the islands of Borneo and Sumatra. Out of the 18 recognized species described before 2002, eight were found in Borneo and seven in Sumatra, whereas only one species was reported from Thailand, three from Peninsular Malaysia, two from Java and two from the Philippines ( $R$. manillana Teschem. and $R$. schadenbergiana Göpp.). The description of $R$. speciosa from Panay Island in the Philippines in 2002, however, marked the start of a period of enormous increase in the knowledge of Philippine Rafflesia. Including R. speciosa, six new Rafflesia species endemic to the Philippines have been described since 2002 (Plate 2, 3). Additional findings include a species from north-eastern Luzon that closely resembles $R$. tengku-adlinii from Borneo (described separately in Barcelona et al. in press; Plate $3 \mathrm{~b}$ ) and another small-sized Rafflesia from Mt Matutum in Mindanao (Barcelona et al. 2006, 2007). Unfortunately, the only specimen preserved of the latter species is too deteriorated to determine its taxonomic identity, but it may very well be a new species. These new discoveries therefore bring the total number of species in the archipelago to ten or eleven (Map 1). In the same period, only two new Rafflesia species were described from outside the Philippines: $R$. azlanii Latiff \& M.Wong (2003) from Peninsular Malaysia and R. bengkuluensis Susatya, Arianto \& Mat-Salleh (2005) from Sumatra. New Rafflesia discoveries since 2002 have brought the total number of currently recognized and described species to 27 and indicate that the Philippines contains ten or eleven species of Rafflesia, at least two more than is found on either Borneo and Sumatra. The Philippines thus has the highest species richness of known Rafflesia of any major geographic entity.

The renewed interest in Philippine Rafflesia that was spurred by the discovery of $R$. speciosa (Barcelona \& Fernando 2002) has not only provided a better estimate of the number of species in the genus, but also resulted in an increase in our knowledge of the only two Rafflesia species known to the archipelago before

() 2009 Nationaal Herbarium Nederland

You are free to share - to copy, distribute and transmit the work, under the following conditions:

Attribution: $\quad$ You must attribute the work in the manner specified by the author or licensor (but not in any way that suggests that they endorse you or your use of the work)

Non-commercia:

You may not use this work for commercial purposes.

For any reuse or distribution, you must make clear to others the license terms of this work, which can be found at http://creativecommons.org/licenses/by-nc-nd/3.0/legalcode. Any of the above conditions can be waived if you get permission from the copyright holder. Nothing in this license impairs or restricts the author's moral rights. 


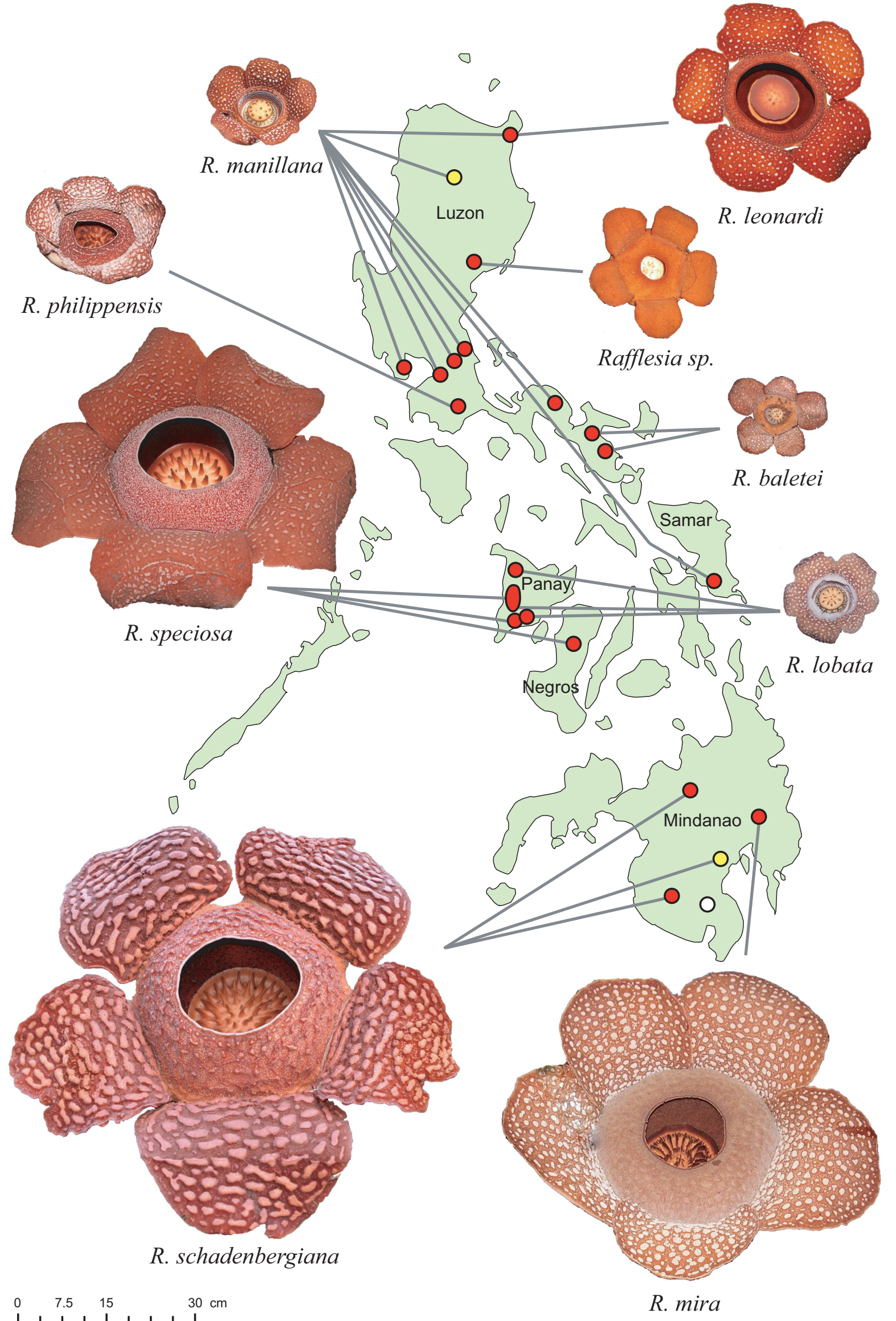

Map 1 Locations of known Rafflesia populations in the Philippines. Red: active populations verified with collections or photographs; yellow: historic populations; white: populations of a small flowered Rafflesia from Mt Matutum on Mindanao. Photographs of Rafflesia flowers are presented scaled according to their relative sizes. All photographs by the authors, except those of R. baletei (M.O. Cajano), R. lobata (R.L. Martin Jr.), R. manillana (A. Diesmos), and R. mira (Department of Tourism, Compostela Valley). 
$R$. speciosa was described. New populations of $R$. manillana were found in Luzon (Plate $2 \mathrm{c}, \mathrm{d}, 3 \mathrm{e}-\mathrm{g}, 4 \mathrm{a}, \mathrm{b}$ ), giving a more accurate view of the distributional range of this species (Map 1). For the first time in 110 years, active (i.e., flower producing) populations of $R$. schadenbergiana have been seen in Mindanao (Lays 2006, Barcelona et al. 2007, 2008a, Plate 2g, 3I-n), a species feared to have gone extinct (Barcelona et al. 2006). Furthermore, the discovery of new Rafflesia populations contributed to a better understanding of infraspecific morphological diversity and ecological preferences of Philippine Rafflesia (Plate 2, 4). Many of these newly found populations are remote from other populations of the same species and are found outside of protected areas. In addition, they consist of very few individuals and are highly threatened by logging, slash-and-burn agriculture (Plate $4 \mathrm{~d}, \mathrm{f}$ ) and disturbance by curiosity-seekers and unsustainable ecotourism (Plate $4 \mathrm{~g}, \mathrm{~h}$ ). The recent interest in Rafflesia in the Philippines has therefore also emphasized the urgent need for effective local conservation strategies to protect these plants from extinction. In this paper, we summarize the current knowledge of Philippine Rafflesia.

\section{KEY TO PHILIPPINE RAFFLESIA}

1. Fully expanded flower less than $40 \mathrm{~cm}$ diam ....... 2

1. Fully expanded flower more than $40 \mathrm{~cm}$ diam . . . . . . 7

2. Diaphragm aperture narrow, less than $1 / 2$ of the diaphragm diam, as wide as or narrower than the diam of the disk, not or only partially exposing inner surface of the perigone tube 3

2. Diaphragm aperture wide, more than $1 / 2$ of the diaphragm diam, wider than the diam of the disk, fully exposing the inner surface of the perigone tube

3. Flowers orange throughout, without whitish warts; ramenta usually more than $5 \mathrm{~mm}$ long. - Luzon .... Rafflesia sp.

3. Flowers orange, dark- or rusty-brown, dark reddish or maroon, perigone with prominent whitish warts; ramenta less than $5 \mathrm{~mm}$ long $\ldots \ldots \ldots \ldots \ldots \ldots \ldots \ldots$

4. Disk creamy white centrally, becoming reddish brown towards the periphery, undersurface (corona) whitish, tan peripherally; processes monomorphic, in two concentric rings; ramenta nearly uniformly distributed from the base of the perigone tube to the diaphragm; diaphragm aperture round, except in flowers disfigured during development; windows (white blots on the lower surface of the diaphragm) absent; flowers often bisexual. - Luzon . . . . . . . . . . . . . . . R. baletei

4. Disk pale yellow or yellowish cream centrally, maroon towards the periphery, undersurface uniformly maroon; processes polymorphic, variously disposed; ramenta polymorphic, scattered, more or less solitary and less-branched in the perigone tube, clustered, larger, stouter and dense inside the diaphragm; diaphragm aperture usually oval; windows present in larger flowers; flowers strictly unisexual. — Luzon

R. philippensis

5. Fully expanded flower $25 \mathrm{~cm}$ or more in diam; disk $7-8 \mathrm{~cm}$ diam, nearly smooth or with poorly developed processes; windows absent. — Luzon . . . . . . . . . . . R. leonardi

5. Fully expanded flower less than $25 \mathrm{~cm}$ diam; disk up to $5 \mathrm{~cm}$ diam, processes well developed; windows present . . . 6

6. Diaphragm lobed, almost snow white in newly opened flowers. - Panay . . . . . . . . . . . . . . . R. lobata

6. Diaphragm usually entire, cream coloured with round or elliptic blots that are sometimes coalescent. - Luzon and Samar R. manillana

7. Disk processes polymorphic, larger ones laminar or platelike, erose, radially disposed; perigone warts round or elliptic, rim of aperture darker than diaphragm. - Mindanao ....
7. Disk processes monomorphic, conical, arranged in concentric rings; perigone warts elongated, rim of aperture whitish or paler than the diaphragm $\ldots \ldots \ldots \ldots \ldots \ldots$

8. Newly opened flowers $52-80 \mathrm{~cm}$ diam, reddish maroon; diaphragm rugose, larger perigone warts $1 \mathrm{~cm}$ or more wide, sometimes coalescent or reticulate, processes more than 40. - Mindanao. . . . . . . . . . . R. schadenbergiana

8. Newly opened flowers $45-56 \mathrm{~cm}$ diam, rusty- or reddish brown; diaphragm generally smooth, larger perigone warts less than $5 \mathrm{~mm}$ wide, free; disk processes less than 40 . — Panay and Negros. . . . . . . . . . . . . . R. speciosa

\section{TAXONOMY}

Rafflesia baletei Barcelona \& Cajano - Plate 2a, 3a, 4e

Rafflesia baletei Barcelona \& Cajano in Barcelona et al. (2006) 232. - Type: Candelaria et al. 5526 (holo PNH; iso CAHUP, K, SING, US).

Diagnostic characters - Rafflesia baletei flowers are (9-) $15-16(-22) \mathrm{cm}$ diam and the smallest in the genus. Depending on age, the perigone lobes are orange or dark, reddish- or rusty-brown. They are erect basally, but recurved apically with one lobe usually noticeably smaller than the rest. The perigone warts are prominently raised and variously shaped. These leave reticulate impressions on the diaphragm that are sharp-edged and irregular in shape, although commonly forming pentagonal areoles. The diaphragm aperture is $3-3.5 \mathrm{~cm}$ diam and has a reddish brown rim, which is darker than the rest of the diaphragm. The disk is $5-5.5 \mathrm{~cm}$ diam, dome-shaped, and glistening creamy white centrally to reddish brown at the periphery. The processes are unbranched (sometimes with small projections), conical, up to $1 \mathrm{~cm}$ long, and arranged in 2 concentric rings. The ramenta are dense, nearly uniformly distributed on the inside of the perigone tube and diaphragm, branched, up to $2 \mathrm{~mm}$ long, and longest at the base of the perigone tube. Windows are absent. The floor of the perigone tube is velutinous. Male flowers have vestigial ovaries and contain 11-14 semi-globose anthers.

Taxonomic notes - Misidentification of an earlier collection of $R$. baletei composed of two dried flowers collected in 1991 (Balete \& Peñas s.n., CAHUP) was responsible for previous reports of $R$. manillana from Mt Isarog (Heaney \& Regalado 1998, Nais 2001, Fernando et al. 2004, Fernando \& Ong 2005).

Distribution — Luzon, Camarines Sur, Mt Isarog and MtAsog (= Mt Iriga).

Ecology \& Conservation - Rafflesia baletei occurs in rocky, riparian habitats (Plate 4e), usually in steep and well-drained secondary forests planted with Musa textilis Née and bamboos at 500-560 m. Peak flowering months are December to May. Although some Rafflesia populations are located in Mt Isarog National Park, a protected area, they are found in areas that are prone to erosion during the typhoon season. In fact, a typhoon in 2006 destroyed much of the Rafflesia population on Mt Isarog when the host vines were brought down by falling trees (M.O. Cajano, University of the Philippines, Los Baños, pers. comm.).

Rafflesia leonardi Barcelona \& Pelser - Plate 1f, h, 2f, 3i, 4c Rafflesia leonardi Barcelona \& Pelser in Barcelona et al. (2008a) 224. - Type: Barcelona et al. 3355 (holo $\mathrm{PNH}$; iso L, PUH, US).

Diagnostic characters - Fully expanded flowers of $R$. leonardi range $25.5-34 \mathrm{~cm}$ diam and are reddish orange in new blooms. The perigone lobes are 5 , seldom 6 , and have tan to pale yellow margins. The powdery white warts on the perigone lobes are prominent, free, mostly round or elliptic. The larger ones are interspersed with tiny ones. The diaphragm is usually 

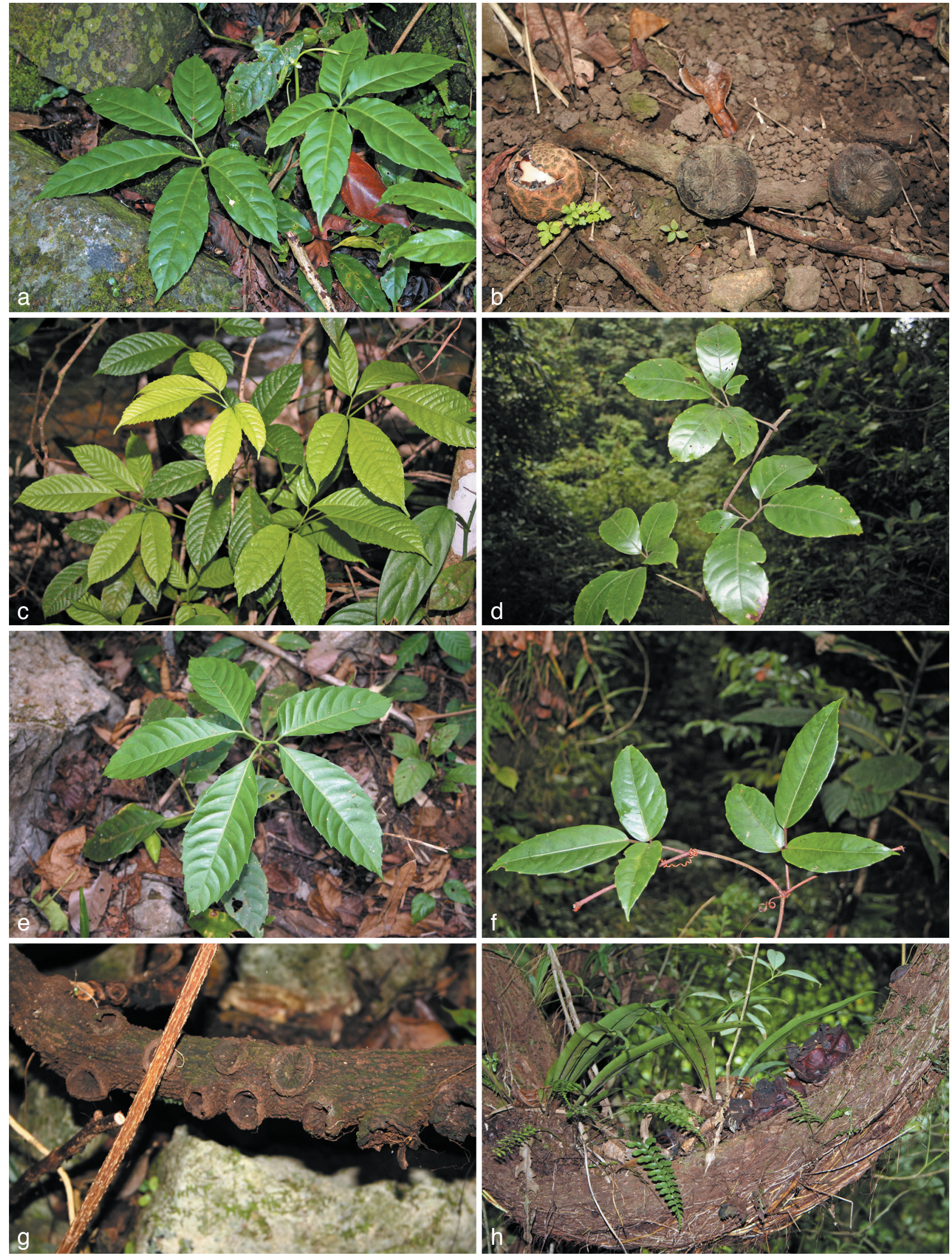

Plate 1 Tetrastigma (Vitaceae) species found as hosts of Rafflesia. a, b. Tetrastigma pisicarpum, host of $R$. philippensis on Mt Banahaw: a. leaves, b. aboveground roots with emerging Rafflesia buds; c. Tetrastigma papillosum, host of $R$. schadenbergiana on Mt Kitanglad; d. Tetrastigma sp., host of $R$. manillana on Mt Natib; e. Tetrastigma sp., host of $R$. speciosa in Sibalom Natural Park; $\mathrm{f}-\mathrm{h}$. Tetrastigma cf. Ioheri, host of both $R$. manillana (in Bolos Point and Kanapawan, and possibly on Mt Labo) and $R$. leonardi (in Kanapawan): f. trifoliate leaves, g. prostrate vine with scars of $R$. manillana flowers, h. host plant of $R$. leonardi. - Photos by J.F. Barcelona. 

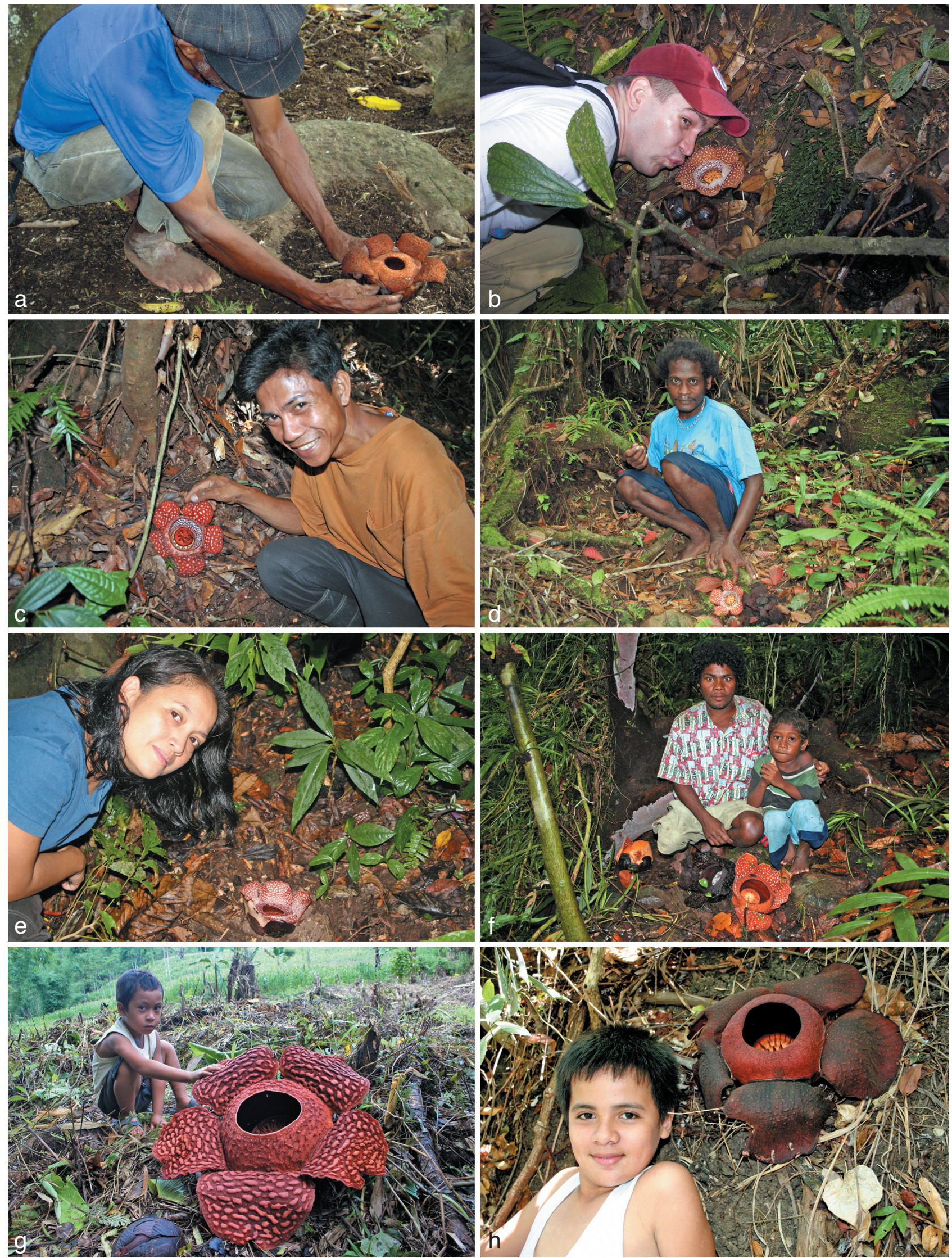

Plate 2 Philippine Rafflesia flowers in situ, showing their relative sizes. a. R. baletei, Mt Isarog; b. R. lobata, Mt Agua Coloña; c. R. manillana, Mt Labo; d. R. manillana, Kanapawan; e. R. philippensis, Mt Banahaw; f. R. leonardi, Kanapawan; g. R. schadenbergiana, Baungon; h. R. speciosa, Valderrama. - Photos by: a, e: M.O. Cajano, b: R.L. Martin Jr., c, d, f-h: J.F. Barcelona. 
14-18 cm diam, but can reach $22 \mathrm{~cm}$ in large specimens. The outer surface of the diaphragm bears shallow perigone wart impressions surrounded by slightly raised ridges that are decorated with tiny tan coloured speckles. Windows are absent. The wide diaphragm aperture, 10.5-12.5(-19) cm diam, is reminiscent of $R$. manillana and $R$. lobata. The rim of the diaphragm is maroon and concolorous or slightly darker than the surrounding tissue. The disk is $7-8 \mathrm{~cm}$ diam, almost flat to slightly dome-shaped with a slightly raised margin. It is tan centrally, purplish maroon towards the periphery, and nearly smooth or with up to 10 poorly developed processes. When present, the processes are tuberculate or sometimes conical and pointed, up to $5 \mathrm{~mm}$ or occasionally somewhat longer, and dark maroon. The ramenta are short, up to $2 \mathrm{~mm}$ long, dimorphic, those toward the base of the perigone tube dense and filiform, those on the lower surface of the diaphragm more sparse and clustered, stout, branched or cleaved apically, and with dark tips. Male flowers are without vestigial ovaries and have 20 or 21 anthers, which are deeply immersed in the anther sulci. The female flowers are as big as the male flowers and are without vestigial anthers. The ovary is c. 1.2 by $6 \mathrm{~cm}$ and lunate in longitudinal section.

Taxonomic notes - The correct spelling of the specific epithet is leonardi but due to a misprint in the original description, it appeared in that one place as leonardii (Barcelona et al. 2008a: 224, line 1).

Distribution - Luzon, Cagayan Province, Gattaran \& Lallo Municipalities, Barangays Bolos Point and Kanapawan.

Ecology \& Conservation - Rafflesia leonardi is found in logged-over lowland dipterocarp forests at 270-300 m. This is, thus far, the lowest elevation confirmed for Rafflesia populations in the Philippines, although $R$. manillana was reported to occur at c. $120 \mathrm{~m}$ on Mt Makiling (E.S. Fernando, University of the Philippines, Los Baños, pers. comm.). The plants grow along river and stream banks on thin soil and rocky substrates (Plate 2f, 4c). Tetrastigma cf. Ioheri Gagnep. was identified as the host plant (Plate 1f). Rafflesia leonardi forms flowers on both the exposed roots and the climbing parts of its host (Plate $1 \mathrm{~h}$ ), occasionally up to a height of c. $10 \mathrm{~m}$ above ground level. A total of six populations were found in the region, which is not currently part of a protected area. One population was sympatric with $R$. manillana.

\section{Rafflesia lobata R. Galang \& Madulid - Plate 2b, 3c, 4f}

Rafflesia lobata R. Galang \& Madulid (2006) 2, PI. 1-10. - Type: Galang et al. 001 (holo PNH).

Diagnostic characters - This species is similar to $R$. manillana in flower size (11-21 cm diam) and gross morphology. It has a wide-open diaphragm aperture fully exposing the inner surface of the perigone tube. The diaphragm is lobed, the lobes are initially incurved, their outer surface nearly smooth, uniformly snow-coloured without warts or speckles during early anthesis becoming outcurved and pale brown with age; windows are present on the inner surface. The annulus is welldeveloped. The disk processes are stout and sometimes poorly developed, having tips with fine black hairs.

Distribution - Panay. Rafflesia lobata was originally described from populations discovered in 2005 on Mt lgtuog and Mt Sakpaw in Sebaste and Pandan municipalities, Antique Province, in the north-western part of Panay Island (Galang \& Madulid 2006). The presence of a population of $R$. lobata on Mt Agua Coloña, part of the mountains bordering the municipality of Leon, Iloilo Province and Antique Province on Panay Island was brought to our attention by members of The Antique Outdoors (TAO), an environmental advocacy group. The same group also led us to a third population of $R$. lobata in the municipality of San Remegio, Antique Province in May 2008. The recent discovery of these populations in the southern part of the island indicates that $R$. lobata may very well be more widespread in Panay than previously thought.

Ecology \& Conservation - Rafflesia lobata grows at 400 $950 \mathrm{~m}$ and is mostly found in gullies in primary or severely degraded lowland rain forest or limestone forest (Plate $4 \mathrm{f}$ ). Just like $R$. manillana, the flowers of this species emerge both on the roots and climbing shoots of its host. It flowers throughout the year, but predominantly from February to June. Galang \& Madulid (2006) mention seven populations of $R$. lobata in Sebaste and Pandan (Antique). Neither of these nor the populations in Leon (lloilo) and San Remegio (Antique) is located in a protected area.

Rafflesia manillana Teschem. - Plate 1d, f, g, 2c, d, 3e-h, $4 a, b$

Rafflesia manillana Teschem. (1842) 63, t. 6. - Rafflesia cumingii R.Br. (1844) 243, nom superfl. - Type: Navarro s.n.? (A n.v., lost?).

Rafflesia lagascae Blanco (1845) 595. - Type: Azaola s.n. (not preserved). Rafflesia panchoana Madulid, Buot \& Agoo (2008, '2007') 43. - Type: W.H. Brown s.n. (Species Blancoanae 535) (holo US904212, erroneously cited in the protologue as US0090412).

\section{Local name - Malabo-o (Tagalog).}

Diagnostic characters - Fully expanded flowers of $R$. manillana range from 11-24 cm diam. The perigone lobes are reddish to rusty brown and ornamented with whitish warts. The diaphragm is more or less erect, sometimes slightly incurved and has an entire rim which shows a narrow whitish band surrounded by a broader, more conspicuous reddish maroon band. The aperture is wide open and exposes the inner structures of the flower including diaphragm windows, and similar smaller white blots on the interior surface of the perigone tube, as well as the disk with processes that are stout, pustular to sometimes rudimentary and tipped with dark brown to blackish hairs. The annuli of male flowers have very clear impressions of the anthers and these are lined by minute tubercles and club-shaped bodies intermixed with fine bristles. The sex of a flower and the number of anthers (ranging from 10-18) in male flowers can therefore easily be determined in $R$. manillana without dissection.

Taxonomic notes - The type of $R$. manillana was composed of three immature buds sent to Teschemacher (most probably by Father Pedro Navarro, a Franciscan naturalist; Blanco 1845: 566) from Basei (= Basey) in Samar Province in 1841. The protologue stated that Basey is located in Leite (= Leyte), but although Samar was indeed governed as part of Leyte Province from 1735 to 1768 (Philippines Census Office 1920: 246), both islands were already separate provinces in Teschemacher's time and Leyte was therefore mistakenly named as the island of the type of $R$. manillana. No additional collections of Rafflesia were made in Samar or Leyte until $R$. manillana was rediscovered in Basey in 2007 (Madulid \& Agoo 2008). Since the type of $R$. manillana is apparently lost, this recent discovery allowed botanists, for the first time in 166 years, to compare the morphology of plants collected near the type locality with those found in Luzon. On the basis of this comparison, Madulid et al. (2008) concluded that the rediscovered $R$. manillana from Samar is a different species from the Luzon populations and consequently, they renamed the Mt Makiling populations previously assigned to $R$. manillana as $R$. panchoana. Among the characters used to differentiate $R$. manillana from $R$. panchoana is the presence of "tuberculous structures at the columnar base and annular rim ..." in flowers of $R$. manillana that are, accordingly, replaced by bristles in R. panchoana. Although Madulid \& Agoo (2008: 65 , PI. $1 \mathrm{~g}$ ) include a photograph of a close-up from a wilted flower to illustrate these structures, we also observed similar 
minute $(<0.5 \mathrm{~mm})$ tubercles mixed with bristle-like structures in flowers of $R$. manillana from Bolos Point, Luzon (Plate $3 \mathrm{~g}, \mathrm{~h}$ ). In addition to the presence of these tubercles, the authors indicate a difference in anther number between the Samar and Luzon populations (10-12 in R. manillana and 14-18 in $R$. panchoana). Anther numbers have, however, only been established for relatively few specimens in both the Samar and Luzon populations. Furthermore, the lower anther number of the Samar population coincides with a flower size that is in the lower range of what is found in the Luzon populations. Anther counts of additional flowers from both islands may eliminate the gap in anther numbers between the Samar and Luzon populations. Other distinguishing characters mentioned by Madulid \& Agoo (2008) are the morphology of the warts of the perigone lobes, the windows, the ramenta, and the shape of the diaphragm. Our own studies of the morphological diversity in the various Luzon populations, however, showed that these characters are quite variable and overlap with the variation reported for the Samar population. The incurved diaphragm mentioned as diagnostic for the Samar population, for instance, has also been observed in flowers from Mt Makiling in Luzon (see Brown 1912, plate 12, fig. 1 \& 2). Because of these very dubious morphological differences between the Luzon and Samar populations and pending examination of plants of the Samar population, we, for now, consider the Luzon populations traditionally assigned to $R$. manillana as indeed conspecific with $R$. manillana Teschem. from Samar. Thus $R$. panchoana is therefore reduced to synonymy here.

The name $R$. panchoana would, however, still also be a synonym if the Luzon and Samar R. manillana populations are shown to be separate species, because an older name is available for this taxon. Rafflesia lagascae was published in the second edition of the Flora de Filipinas (Blanco 1845) and we follow Merrill $(1918,1923)$ in recognizing this name as an earlier synonym for the Luzon populations of $R$. manillana. Both $R$. lagascae and $R$. philippensis (another Rafflesia species published in Blanco's Flora) were described from Monte de Majaijai (= Mt Banahaw; Global Volcanism Program website, Smithsonian Institution) that were collected by Iñigo Gonzales y Azaola. Unfortunately, these specimens were not preserved and Rafflesia was not encountered on Mt Banahaw since Azaola until recently on this mountain (Madulid et al. 2007, Barcelona et al. 2007). Although Merrill considered both names synonyms of $R$. manillana $(1918,1923)$, only the description of $R$. lagascae matches $R$. manillana, which occurs on nearby Mt Makiling, and may have recently again been found on Mt Banahaw (E.S. Fernando, University of the Philippines, Los Baños, pers. comm.). Blanco's posthumously published notes of the specimens of $R$. lagascae described to him by Azaola, for instance, mention the reddish maroon band at the rim of the diaphragm aperture characteristic of $R$. manillana from Luzon: “... a exception de la línea circular de caliz que es de color pardo rojizo...” (p. 595). Moreover, Blanco's text refers to the black silky hairs of the processes, which are only found in $R$. manillana and $R$. lobata: "Del centro de dicho caliz se eleva una columna truncada ... y en su superficie se ven varios puntos, salientes de color negro, dotados de sedas negras con lámina sin pistilo" (p. 595). Only the size of the open flower of $R$. lagascae deviates from what is found in $R$. manillana, being much larger (c. 1 foot), but this is likely a very rough size estimate. In addition to the morphological characters mentioned in the description of $R$. lagascae and its proximity to areas where $R$. manillana have been found, the elevation that Azaola recorded for this species suggests that both names apply to the same species. The protologue of $R$. lagascae indicates that it was found between c. 1 085-1 $117 \mathrm{~m}$ (“... a la altura de seiscientas sincuenta á setescientas brazas sobre el nivel del mar ...", Blanco 1845: 595) and this elevation is close to the highest elevation recorded for $R$. manillana on Mt Makiling (c. 1000 m) (M.O. Cajano, University of the Philippines, Los Baños, pers. comm).

Rafflesia cumingii is a name based on the type of $R$. manillana and therefore superfluous. Brown rejected the latter name as he found it inappropriate. The rest of Brown's paper (Brown 1844), however, was based on Cuming s. n., which probably prompted Meijer to state that "the type of $R$. cumingii is a Cuming collection at BM, most likely from the same site as the Navarro collection seen by Teschemacher" (Meijer 1997: 27).

Distribution - Luzon and Samar. Until recently, in the absence of finding $R$. manillana populations at the historical collection sites in Kalinga in northern Luzon (Merrill 1923), Samar (Teschemacher 1842, Meijer 1997, Nais 2001), or elsewhere in the Philippines, the only known active population of $R$. manillana was located on Mt Makiling in Laguna Province in Luzon. It is only since 2005 that additional populations of $R$. manillana have been found, thus expanding our knowledge of the geographical range of this species. These findings indicate a distributional area in Luzon stretching from Mt Labo in Camarines Norte (Barcelona et al. 2006) in south-eastern Luzon to Mt Natib in Bataan Province (Barcelona et al. 2006) in the west and Barangay Bolos Point, Gattaran and Barangay Kanapawan, Lallo Municipalities, Cagayan Province in the northern part of the island (Barcelona et al. 2008a). In addition to these localities and Mt Makiling, photographic evidence indicates that $R$. manillana is also found on Mt Kayapo in General Nakar, Quezon Province (N. Bartolome, Conservation InternationalPhilippines, pers. comm.), and very recently, on Mt Irid, Rodriguez (= Montalban), Rizal Province (pers. obs. by DSB). The present geographical range of $R$. manillana, therefore, seems to consist of Basey in Samar and the majority of Luzon (Map 1). A Rafflesia specimen collected in 1991 on Mt Isarog in Camarines Sur (Balete \& Peñas s.n., CAHUP) and thought to be R. manillana (Heaney \& Regalado 1998, Madulid 2000, Nais 2001, Barcelona \& Fernando 2002, Fernando et al. 2004, Fernando \& Ong 2005) proved to be a different species, $R$. baletei (Barcelona et al. 2006).

Ecology \& Conservation - Rafflesia manillana is found in openings in dipterocarp forests up to $1200 \mathrm{~m}$, although it is more common at lower elevations (as low as $120 \mathrm{~m}$ ). It most frequently grows in forest gaps or margins, and along river- and stream-banks or trails (Plate 4a). The flowers emerge both on the roots and climbing shoots of their host (Plate $1 \mathrm{~g}, 2 \mathrm{c}, \mathrm{d}$ ). In Bolos Point (Cagayan Province), the host Tetrastigma is found in karst limestone forest (Plate $4 \mathrm{~b}$ ), the first record of this habitat type with a Philippine Rafflesia. The host species identified for the population of $R$. manillana at Bolos Point, Tetrastigma cf. loheri, is morphologically similar to the host of the population on Mt Labo, R. mira of Compostella Valley (Fernando \& Ong 2005), and $R$. leonardi which grows sympatrically with $R$. manillana in Kanapawan (Plate 1f, g). One population of $R$. manillana in Kanapawan is peculiar in that all the flowers have lobed diaphragms (Plate $3 \mathrm{~g}$ ). Although irregular in number, shape and size, the diaphragm lobes in this population resemble those observed in $R$. lobata of Panay (Plate 3c). The diaphragm lobes of $R$. lobata, however, are more pronounced. Since the majority of the populations of $R$. manillana in Cagayan Province possess the typical entire diaphragm, until further study, we consider the lobed diaphragm in this species as a morphologically deviant variant without taxonomic significance.

Despite being the most common and having the largest range of all known Philippine Rafflesia species, $R$. manillana has a patchy distribution with relatively small populations in widely separated forest fragments. Except for those on Mt Makiling and Mt Natib, all other known populations of this species are 

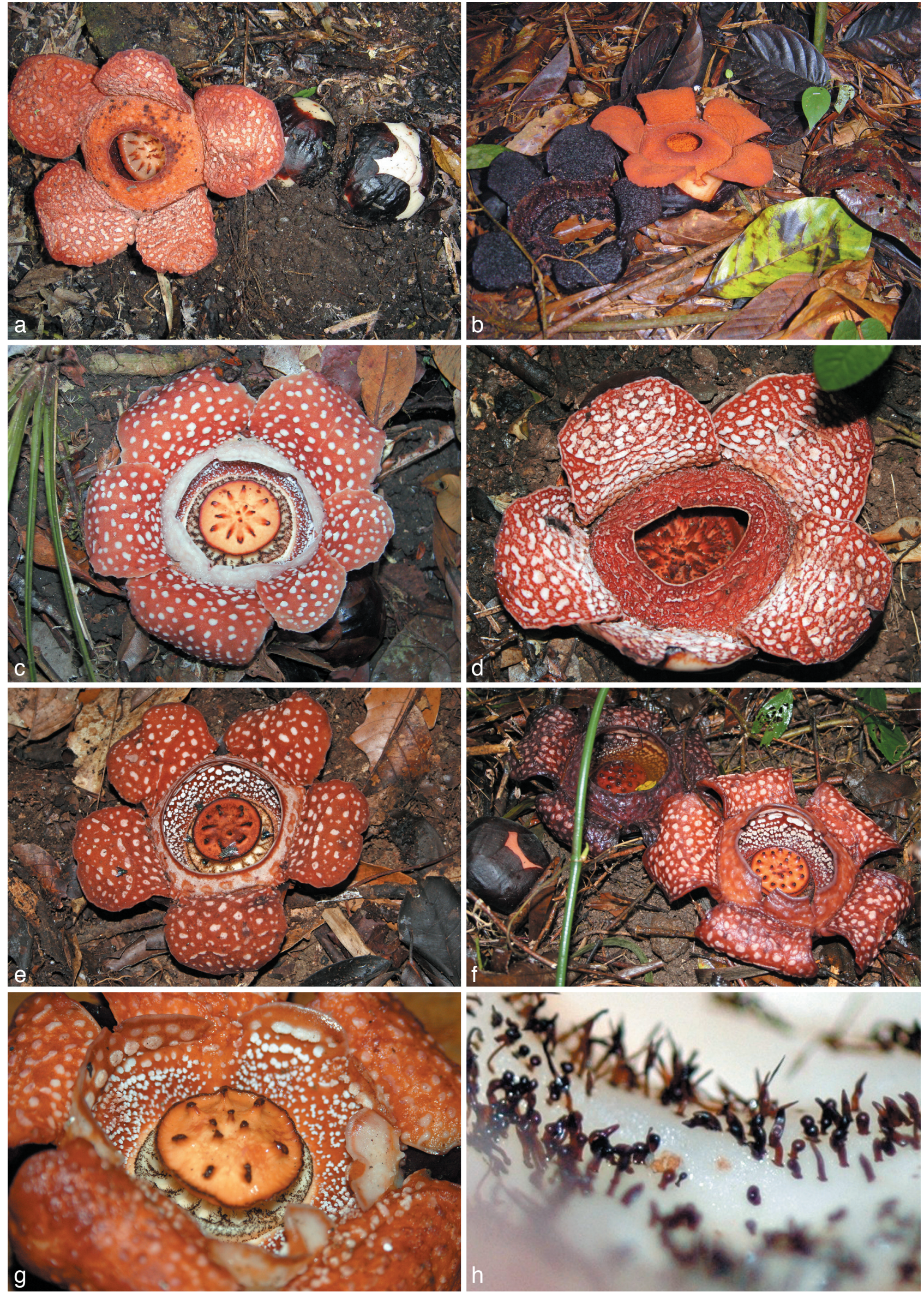

Plate 3 a-I. Philippine Rafflesia species. a. R. baletei, Mt Isarog; b. Rafflesia sp., Sierra Madre Mountains; c. R. lobata, Mt Agua Coloña; d. R. philippensis, Mt Banahaw; e. R. manillana, Mt Labo; f. R. manillana, Mt Natib; g, h. R. manillana, Kanapawan; i. R. leonardi, Kanapawan; j. R. speciosa, Valderrama; k. R. mira, Mt Candalaga; I-n. R. schadenbergiana, Baungon; o, p. Rafflesia as symbol for nature conservation, Buruyluganay Festival, Panay. Antique Prov. Sibalom. — Photos by: a: M.O. Cajano, b: D.S. Balete, c: R.L. Martin Jr., d-f, i, j, I-p: J.F. Barcelona, g, h: B. van Ee, k: Department of Tourism, Compostela Valley Province, Region XI, Mindanao. 

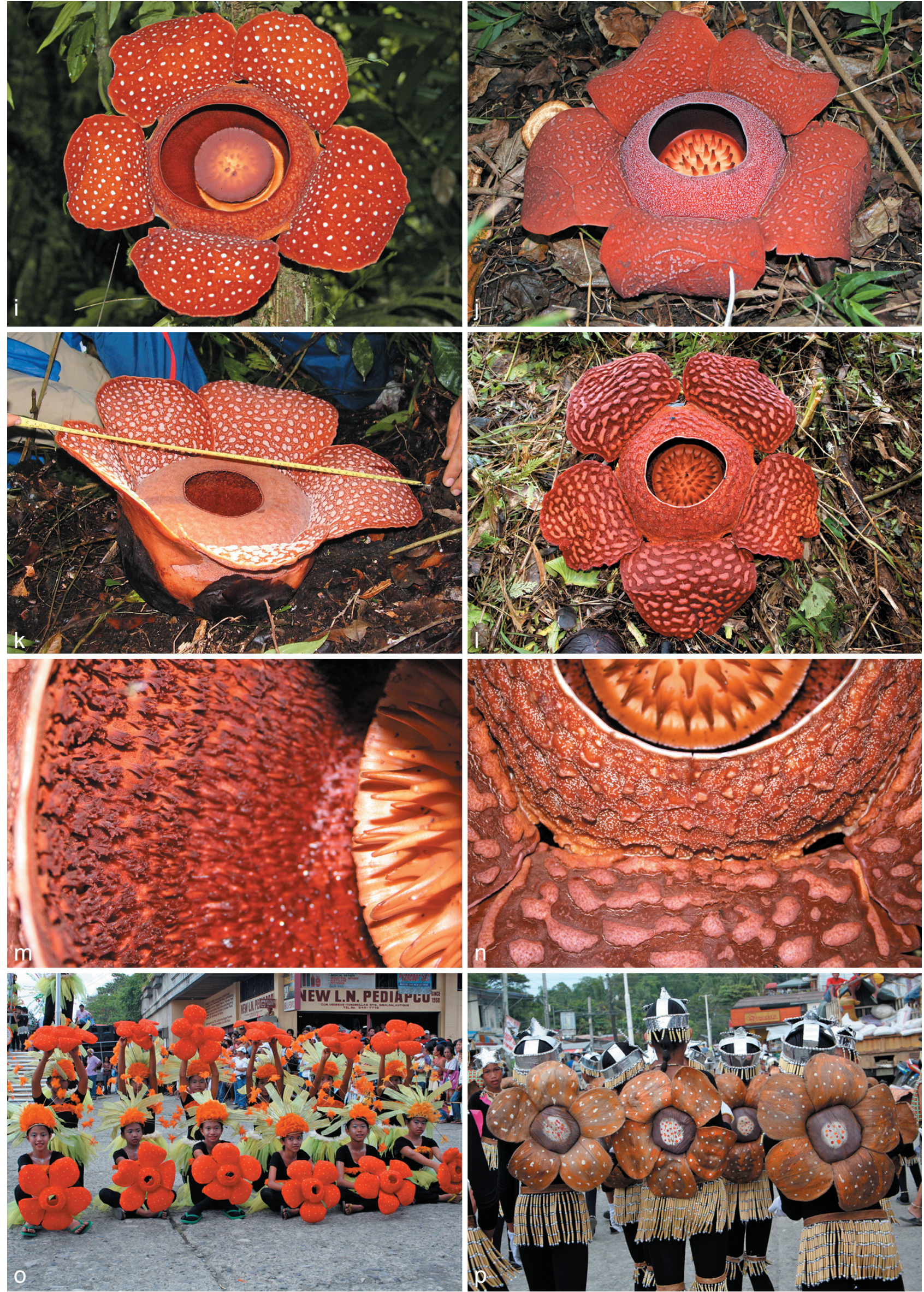

Plate 3 (cont.) 


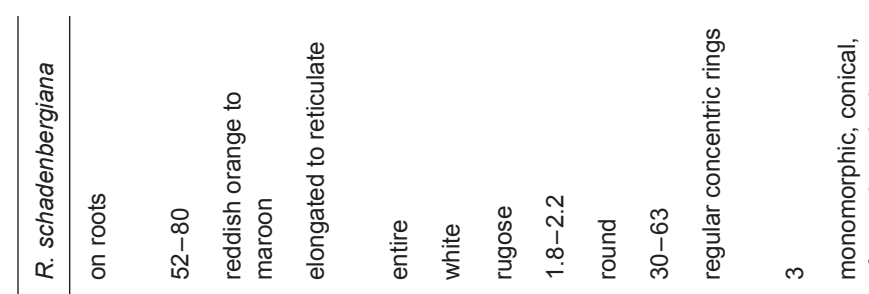

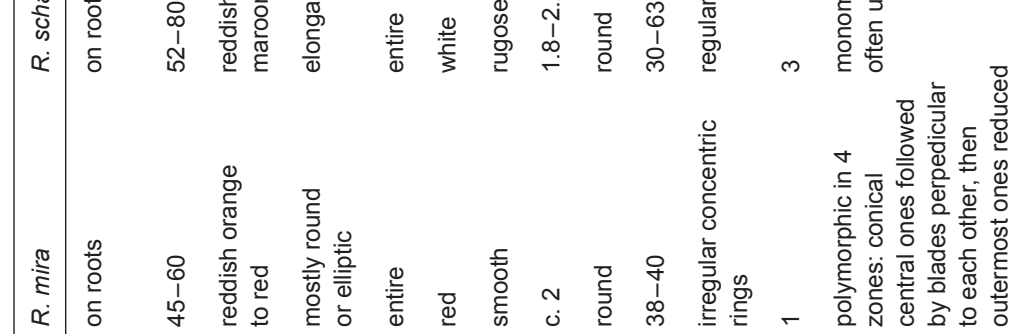

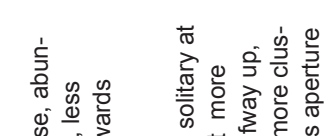

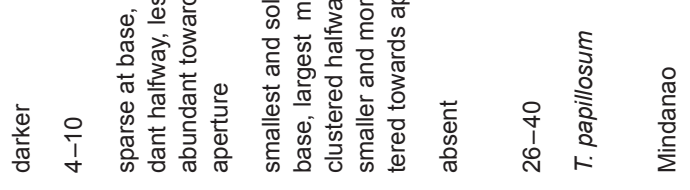

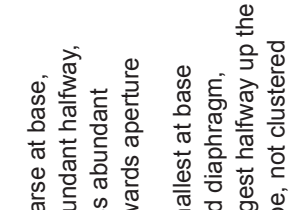

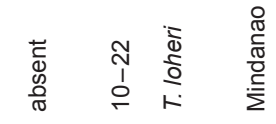

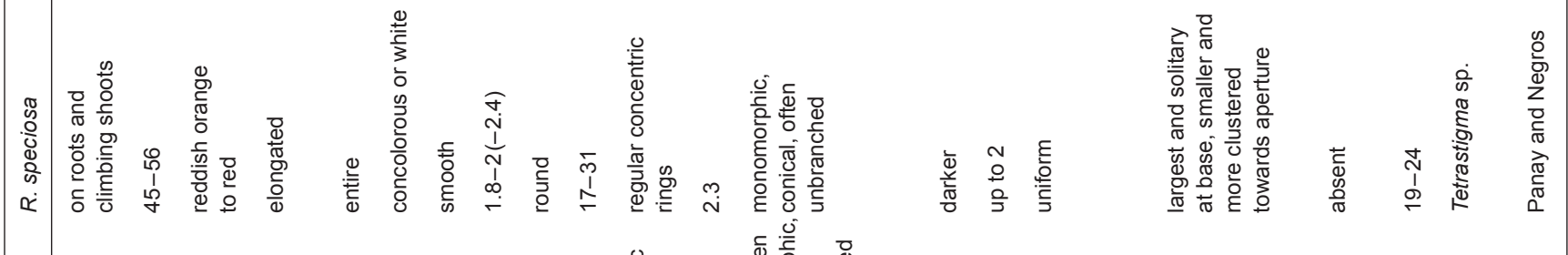

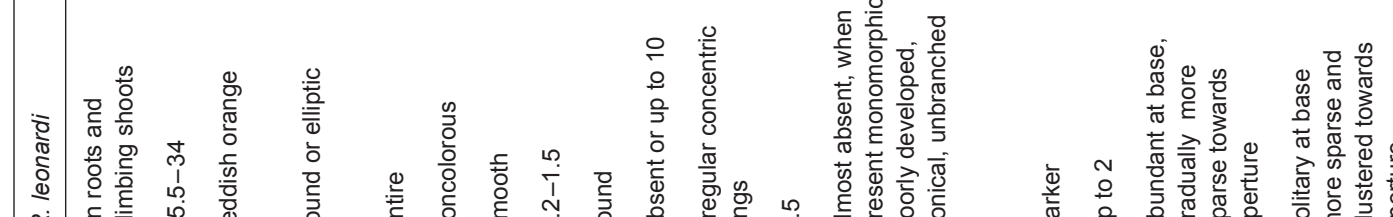

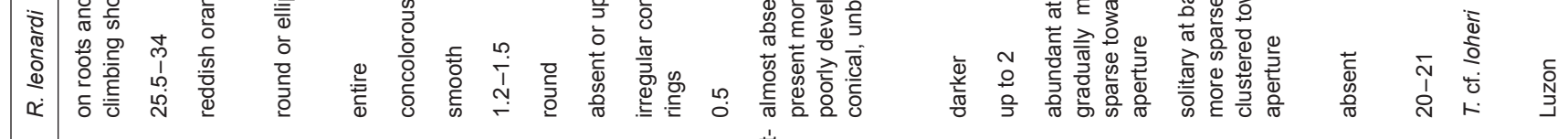

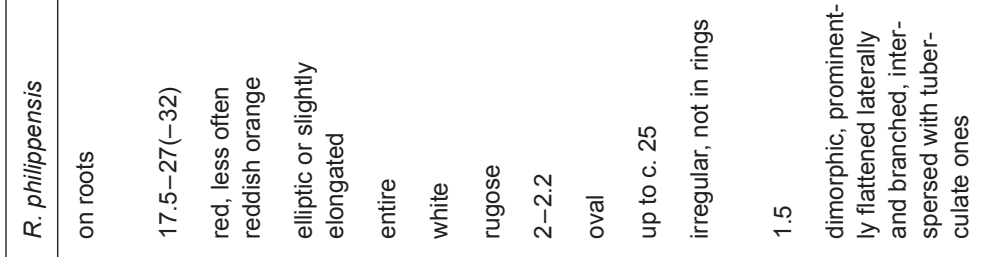

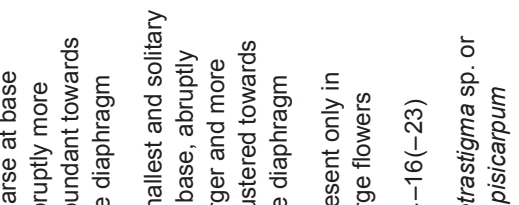

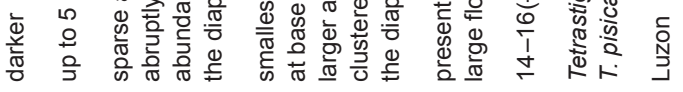

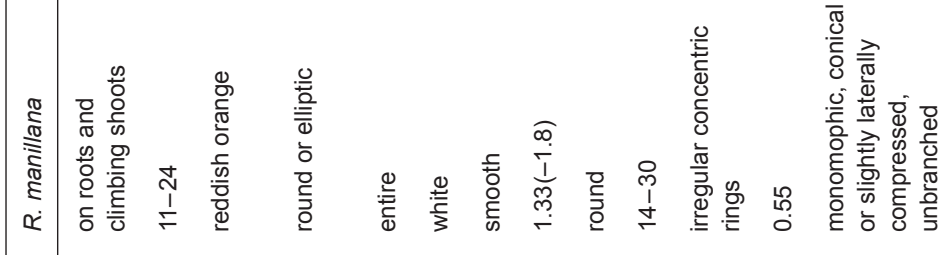

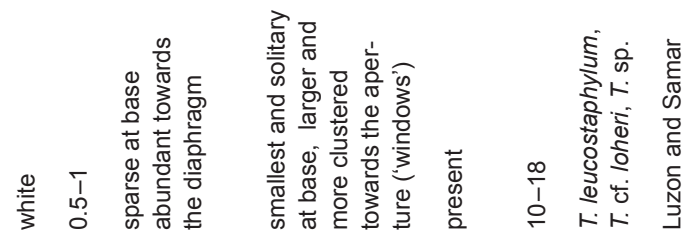

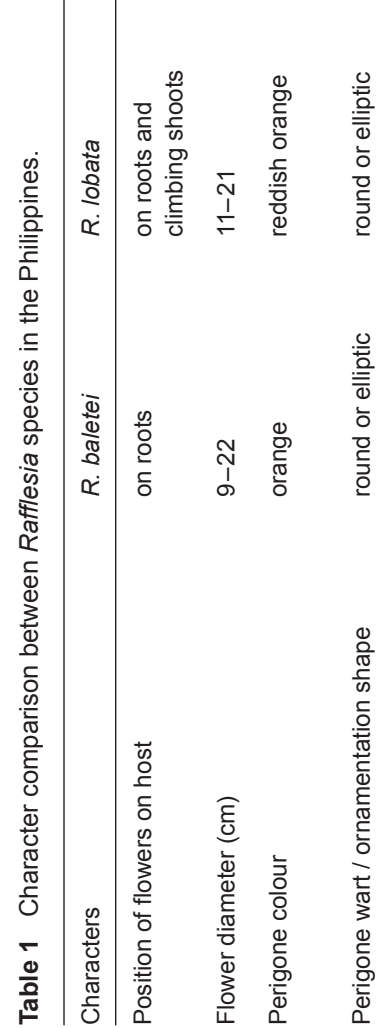

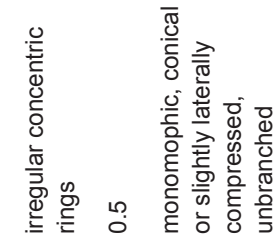

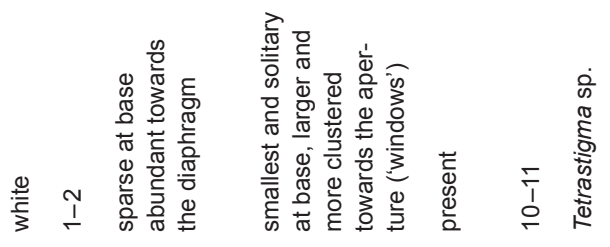

I

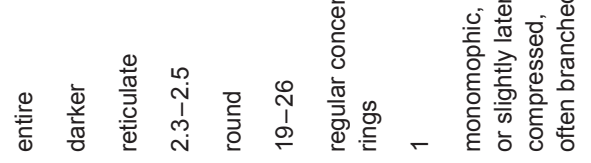

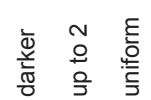

m

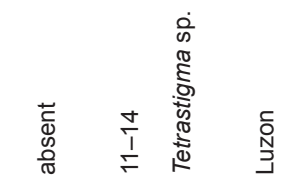

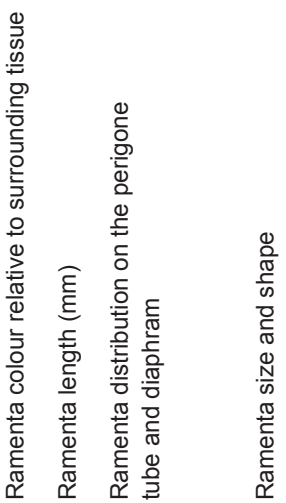

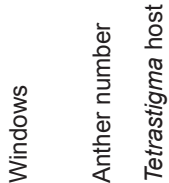

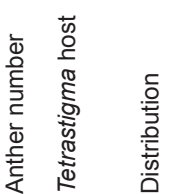


growing outside protected areas. The population at Bolos Point is, however, located in the proposed north-eastern Cagayan Protected Area Landscape, thus helping to emphasize the importance of this area receiving protected status. Rafflesia manillana should therefore still be considered rare and endangered (Tan et al. 1986, Gruèzo 1990, Meijer 1997, Madulid 2000, Nais 2001, Barcelona \& Fernando 2002) and is currently classified as Critically Endangered (DENR-DAO 2007-01).

\section{Rafflesia mira Fernando \& Ong - Plate 3k}

Rafflesia mira Fernando \& Ong (2005) 267. — Type: Fernando \& Ng 1653 (immature bud, LBC).

Rafflesia magnifica Madulid, Tandang \& Agoo (2006, '2005') 3. - Type: Badilla 001 (PNH).

Diagnostic characters - With a floral diam of $45-60 \mathrm{~cm}$, $R$. mira, like $R$. speciosa, belongs to Meijer's medium-sized Rafflesia species (Meijer 1997). The flowers are coloured with different hues of orange and reddish- or rusty-brown. Rafflesia mira has a diaphragm that is nearly smooth (i.e., with none or only shallow impressions of the perigone warts) and slightly darker in colour than the perigone lobes in newly open flowers, but lighter in colour than the perigone lobes with age. In R. mira, a dark red ring surrounds the rim of the diaphragm aperture. The perigone lobes have whitish rounded warts that are free but interspersed with smaller ones. These small warts also line the margin of the perigone lobes. The disk processes are organized in 4 distinct zones and this arrangement is quite characteristic for this species. The innermost, central processes are solitary and more or less conical. They are surrounded by laterally compressed, blade-like processes that are smaller and narrower than the similarly compressed third zone perpendicular to it. The third layer occupies nearly half of the disk diameter. The outermost zone is composed of smaller and narrower processes.

Taxonomic notes - Examination of their types and protologues showed that $R$. mira and $R$. magnifica are two names for the same species (Barcelona et al. 2007). Discrepancies in size measurements in the protologues are perhaps due to the fact that the type of $R$. mira is an immature bud. The description in the protologue of $R$. mira was based only on senescent flowers and some buds, and colour descriptions were based on photographs (E.S. Fernando, University of the Philippines, Los Baños, pers. comm.). Rafflesia magnifica was published in July 2006, despite the publication date of 2005 mentioned in the protologue and is a later synonym.

Distribution - Mindanao. This species has only been recorded on Mt Candalaga in Maragusan Municipality, Compostela Valley Province.

Ecology \& Conservation - Unlike other Rafflesia species that flower the whole year round (although flowering seems to peak from March to May), R. mira flowers from August to November. This species is restricted to semi-open habitats, especially near waterfalls, in mid-montane rain forests at c. $900 \mathrm{~m}$. Its hosts have been identified as Tetrastigma Ioheri (Fernando \& Ong 2005) and T. mutabile (Blume) Planch. (listed as T. tuberculatum (Blume) Latiff, a nom. illeg. in Madulid et al. 2006). The populations of $R$. mira are currently not in a nationally declared protected area. Rafflesia mira is only known from populations that are extremely vulnerable to human disturbance. The presence of Rafflesia on Mt Candalaga has been the main attraction of ecotourism activities in Compostela Valley Province, especially during the peak flowering months. Accordingly, $R$. mira flowers are occasionally being brought down from the mountain for visitors to see, a practice that greatly endangers the survival of these populations.

\section{Rafflesia philippensis Blanco - Plate 1a, b, 2e, 3d}

Rafflesia philippensis Blanco (1845) 565. - Type: Azaola s.n. (not preserved). Neotype designated here: Barcelona, Cajano \& Mendua 3345 (PNH; iso CAHUP).

Rafflesia banahawensis Madulid, Villariba \& Agoo (2007, '2006') 45. — Type: MEUF 101 (PNH n.v.).

Rafflesia banahaw Barcelona, Pelser \& Cajano (2007) 346. — Type: BarceIona, Cajano \& Mendua 3345 (holo $\mathrm{PNH}$; iso CAHUP).

Diagnostic characters — Rafflesia philippensis belongs among the small-sized Rafflesia, producing flowers with a diam of 17.5$27(-32$ ? $) \mathrm{cm}$. The flowers are dark red or maroon, less often orange in fresh blooms. As in $R$. baletei, the warts on the perigone lobes are powdery white, prominent, variably shaped, and often confluent and elongated. The diaphragm is conspicuously rugose, $8-13 \mathrm{~cm}$ diam and has an often oval aperture of $2.5-6 \mathrm{~cm}$; the rim is whitish and resembles the margin of the perigone lobes. Unlike the similarly-sized $R$. manillana and R. lobata, windows (Nais 2001) or white blots (Meijer 1984) in the perigone tube of $R$. philippensis are elongated and prominent only in larger flowers. The disk is $6-8.5 \mathrm{~cm}$ diam and carries variably shaped processes that are up to $1.5 \mathrm{~cm}$ long. The ramenta are polymorphic, up to $5 \mathrm{~mm}$ long, and glabrous. Those inside the perigone tube are more or less solitary and less branched than those inside the diaphragm which are clustered, more dense and stout, but becoming nearly absent towards the diaphragm rim. This does not conform with the protologue of $R$. banahawensis (a synonym of $R$. philippensis, see below) that claims the ramenta are uniformly filiform. The anthers are 14-23 in number and deeply immersed in the anther sulci.

Taxonomic notes - Rafflesia philippensis was described by Blanco in the second edition of his Flora de Filipinas (1845) based on specimens from Monte de Majaijai (= Mt Banahaw), Luzon collected by Iñigo Gonzales y Azaola on 20 April 1840. Unfortunately, Blanco did not preserve the type. Later, Merrill (1918: 135) selected a specimen from Mt Makiling (W.H. Brown s.n., Species Blancoanae 535, PNH lost, US904212) as representative for $R$. philippensis and listed it, with $R$. lagascae, as a synonym of $R$. manillana. After Azaola's discovery of the two species, Rafflesia was not again found on the mountain until recently when a Rafflesia species was encountered and described as $R$. banahawensis by Madulid et al. (2007) and also R. banahaw by Barcelona et al. (2007). Both teams of researchers, however, overlooked the close similarities between this taxon and R. philippensis. After studying Blanco's description (1845), we conclude that these three names conform with the same species and that the specimen that Merrill selected as representative of $R$. philippensis is actually $R$. manillana. In Blanco's description of $R$. philippensis, he records what he calls the 'calyx' as being rough and somewhat woody. This seems to resemble the conspicuous, yet finely rugose diaphragm of $R$. banahawensis. In addition, the size of the male flower (9 inches or $22.86 \mathrm{~cm}$ ) in Blanco's description is within the size range of $R$. banahawensis $(17.5-32 \mathrm{~cm})$, although also in the range of most small-sized Philippine Rafflesia, such as $R$. manillana from Luzon, $R$. lobata, $R$. baletei, and Rafflesia sp. from Quirino Prov., northern Luzon (but see discussion under $R$. manillana). The number of anthers (10), on the other hand, is more within the range of $R$. manillana from Samar $(10-12)$ rather than $R$. manillana from Luzon $(14-18)$ or $R$. banahawensis (14-16(-23)). However, since only a few flowers of $R$. manillana were sampled and only one male flower of $R$. philippensis was described by Blanco, it may very well be that the discrepancy in anther number is not consistent. In Rafflesia, the range of quantitative morphological measurements (such as flower diameter and number of anthers) in different flowers of the same species or even in different flowers from the same host can be large (Table 1; Madulid \& Agoo 2008: t. 1). For 

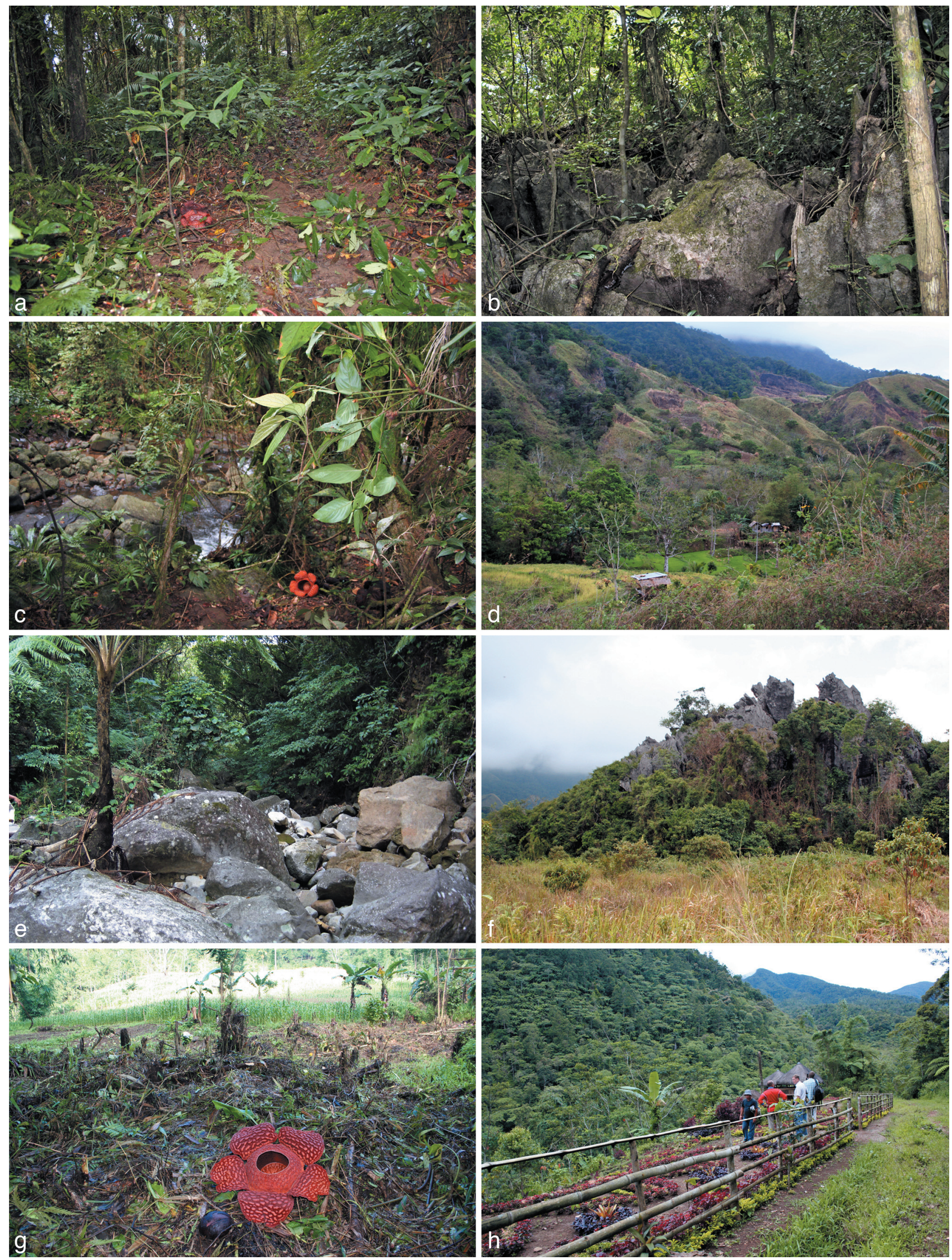

Plate 4 a-g. Habitat of Philippine Rafflesia species. a. R. manillana along a hiking trail, Mt Natib; b. karst limestone forest home to R. manillana, Bolos Point; c. R. leonardi on a stream bank, Kanapawan; d. forest patches containing $R$. speciosa amongst grass fields, San Remegio; e. rocky habitat of $R$. baletei, Mt Isarog; f. limestone outcrop near $R$. lobata site, San Remegio; g. forest patch bordered by slash-and-burn area home to $R$. schadenbergiana, Baungon; h. Ecotourism facilities for R. schadenbergiana, Baungon. — Photos by: a-d, f-h: J.F. Barcelona; e: M.O. Cajano. 
instance, the holotypes of $R$. banahawensis and $R$. banahaw came from a single host plant but the measurements of the flower diam given in both protologues are not even overlapping (29.5-32 cm in Madulid et al. (2007) and 17.5-27 cm in Barcelona et al. (2007))! On the basis of Blanco's descriptions, we therefore conclude that $R$. philippensis is the same species as $R$. banahawensis.

Distribution - Luzon, Laguna and Quezon Provinces, Mt Banahaw.

Ecology \& Conservation - Rafflesia philippensis occurs at $720-750 \mathrm{~m}$ in recovering lowland dipterocarp forest. Madulid et al. (2007) list Tetrastigma pisicarpum (Miq.) Planch. as its host. The five known populations are found on steep slopes and beside seasonal creeks and rivers on well-drained sandy soil with dense herbaceous covering or thick leaf litter (Plate 2e) (Barcelona et al. 2007). Most populations are situated in disturbed habitats, such as along trails, margins of vegetable gardens, and near campsites. For decades, Mt Banahaw has been a popular tourist destination, attracting hundreds of thousands of visitors. In 2004, in an effort to relieve pressure on the area, the Mt Banahaw-San Cristobal Landscape was declared a Protected Area and was temporarily closed to the public for rehabilitation. The discovery of $R$. philippensis came two years after this closure and is perhaps a sign of recovery of the area.

Rafflesia schadenbergiana Göpp. - Plate 1c, 2g, 3l-n, 4g, h

Rafflesia schadenbergiana Göpp. (in Hieron. 1885, '1884') 35. - Type: Schadenberg \& Koch s.n. (holo K; iso WRSL n.v.)

Local names - Kolon Busáw (Higaonon); Bó-o (Bagobo).

Diagnostic characters - Rafflesia schadenbergiana is the largest flower in the Philippines measuring between 52 (Barcelona et al. 3342, $\mathrm{PNH}$ ) and $80 \mathrm{~cm}$ diam when fully expanded. A collection of one fully open male flower (Barcelona et al. $3357, \mathrm{PNH}$ ) is $70 \mathrm{~cm}$ diam, $22 \mathrm{~cm}$ tall, and weighs c. $5 \mathrm{~kg}$. The cupule is c. $5 \mathrm{~cm}$ long, $10-16 \mathrm{~cm}$ wide and has bracts $17-21$ by $12-15 \mathrm{~cm}$. The perigone lobes are $20-23$ by $22-26 \mathrm{~cm}$, orange brown with whitish warts in fresh blooms, but becoming dark maroon with age. The warts on the perigone lobes are 2-3 $\mathrm{mm}$ tall from the perigone surface, the largest being 0.8 by 12 $\mathrm{cm}$. They are variously sized and shaped, the larger ones being conspicuously elongated. The diaphragm is $\mathrm{c} .33 \mathrm{~cm}$ diam and $6-13 \mathrm{~cm}$ wide from the junction of the perigone attachment to the aperture rim. Its upper surface is rugose because of c. 3 $\mathrm{mm}$ deep impressions of the perigone warts. The diaphragm aperture is $13-15 \mathrm{~cm}$ diam with a c. $3 \mathrm{~mm}$ wide tannish ring around the rim. The disk is $12-18 \mathrm{~cm}$ diam, c. $2 \mathrm{~cm}$ thick, c. 5 $\mathrm{cm}$ high from the perigone tube floor to the surface of the disk and pale orange brown or tan with a raised rim c. $2 \mathrm{~cm}$ high. A total of about 30-50 (to 63 in a large senescent flower) up to $3 \mathrm{~cm}$ long cone-shaped processes are arranged in 3 concentric rings (the outermost, middle, and innermost rings of one flower we studied are composed of 27, 14, and 9 processes, respectively). The perigone tube lacks windows and is c. 22 $\mathrm{cm}$ high from the floor of the tube to the rim of the diaphragm. The ramenta are 4-10 $\mathrm{mm}$ long, maroon with darker tips, and often branched from the middle. Those at the base or on the floor of the perigone tube are sparse and filiform, halfway up the tube they are most dense, and those close to the rim of the diaphragm are up to $4-5 \mathrm{~mm}$ long, stout, and clustered in groups. Male flowers have 26-40 anthers. The base of a developing fruit measures c. $14 \mathrm{~cm}$ diameter. A collection of an immature female bud (Barcelona et al. 3358, $\mathrm{PNH}$ ) has a diameter of $16 \mathrm{~cm}$. The disk of this specimen is $17 \mathrm{~cm}$ diam and $2 \mathrm{~cm}$ thick. The column is $12 \mathrm{~cm}$ high from the attachment on the host plant to the surface of the disk. The column neck is
$1 \mathrm{~cm}$ long and $14 \mathrm{~cm}$ wide. The ovary is lunate in longitudinal section, $8 \mathrm{~cm}$ wide and $1.5 \mathrm{~cm}$ high. The annulus is $\mathrm{c} .3 .5 \mathrm{~cm}$ wide.

Distribution - Mindanao. Rafflesia schadenbergiana was first collected on Mt Parág near Mt Apo on Mindanao in 1882 (Lays 2006). Despite search efforts in recent times (e.g., Heaney \& Regalado 1998, Nais 2001), it was not encountered for more than 100 years and was even thought to be extinct (Barcelona et al. 2006). In 1994, however, a flower bud of this species was found in South Cotabato Province in an area locally named Sugud Ebang in the vicinity of Mt Temlofung (Lays 2006) and in 2007, a third locality was discovered at the foot of Mt Kitanglad in Bukidnon Province, about $150 \mathrm{~km} \mathrm{NNW}$ of the type locality at c. $820 \mathrm{~m}$ (Barcelona 2007, Barcelona et al. 2008b). The distributional area of the largest Rafflesia of the Philippines, therefore, seems to cover a large part of Mindanao. The reported finding of $R$. schadenbergiana on Mt Matutum is erroneous (see Nais 2001: 98, 175).

Ecology \& Conservation - Rafflesia schadenbergiana has been reported from old growth primary mountain forest at $1271 \mathrm{~m}$ in South Cotabato Province (Lays 2006) and in a small patch of secondary forest in the vicinity of a river on Mt Kitanglad at c. $820 \mathrm{~m}$ (Barcelona 2007, Barcelona et al. 2008b). The latter population borders a slash-and-burn area (Plate $2 \mathrm{~g}, 4 \mathrm{~g}$ ) and relies on a single host plant. This host, Tetrastigma papillosum Planch. (Barcelona 3343 with Antoque and Barcelona et al. $3360, \mathrm{PNH})$, has a dbh of c. $15 \mathrm{~cm}$ (Plate 1c).

The R. schadenbergiana population described by Barcelona (2007) and Barcelona et al. (2008b) is located outside of the Mt Kitanglad Range Natural Park, a protected area, and although initial steps were taken to protect the plants and their habitat (Barcelona et al. 2008b), a visit to the area in November 2007 showed considerable damage resulting from unsustainable ecotourism activities. The site was converted into a mountain resort where the immediate vicinity was cleared and planted with ornamental plants. Native huts were established as resting areas for potential visitors (Plate $4 \mathrm{~g}, \mathrm{~h}$ ). We found several aborted buds and have witnessed the intentional search for Rafflesia buds and flowers; activities which subject the Rafflesia plants and the roots of their host vine to trampling by caretakers and visitors. Potentially, the clearing of the immediate vicinity also endangers seed germination and exposes seeds and buds to predation. In May 2008, a workshop on a conservation strategy for $R$. schadenbergiana was conducted by the DENR with the barangay officials, Local Government of Baungon Municipality, representatives from the Department of Tourism, parasitic plant experts, and the landowner and as of this writing, a conservation action plan is being prepared. We now have information that another population of a large-sized Rafflesia, potentially $R$. schadenbergiana, is found inside the protected area. Flowering specimens were, however, not encountered in this new population, and only buds and senescent flowers were seen and photographed. Currently, the best conservation measure for this population is not to disclose its exact location until a conservation strategy has been developed. So, although not extinct as was assumed until recently (Barcelona et al. 2006), $R$. schadenbergiana is extremely rare and one of its two (perhaps three) known and active populations is Critically Endangered (DENR-DAO 2007-01).

The strong unpleasant flower odour was noted by the first collector, a German pharmacist practicing in the Philippines, Alexander Schadenberg, who for that reason was reported to be very upset when the species was given his name (Anonymous 1930). 
Rafflesia speciosa Barcelona \& Fernando - Plate 1e, 2h, 3j, 4d

Rafflesia speciosa Barcelona \& Fernando (2002) 648. - Type: Barcelona 1221 (holo $\mathrm{PNH}$; iso LBC).

Local names — Urúy, Kalò Posong, Agong-ong (Karay-a).

Diagnostic characters - Fully expanded flowers of $R$. speciosa range from $45-56 \mathrm{~cm}$ diameter. The perigone lobes are generally dark-, reddish- or rusty-brown, but become paler with age. The white warts on the perigone lobes are small and irregular in shape and are often free and elongated. The diaphragm is usually darker than the perigone lobes and has an almost smooth surface with numerous small and irregular white specks which are most prominent in new blooms; its rim is whitish becoming concolorous with age. The disk is yellow-orange, but becomes more reddish orange near the rim. Rafflesia speciosa has 17-31 processes which are usually arranged in 2 or 3 concentric rings pointing outward towards the rim. This species is larger than most other Philippine Rafflesia, similar in size to $R$. mira and small flowers of $R$. schadenbergiana. It is clearly different from both those species in flower colour, the shape and pattern of the warts on the perigone lobes, diaphragm morphology, and the shape and number of the processes.

Distribution - Panay and Negros. Rafflesia speciosa was described from Mt Poras in Antique Province in Panay Island, but has also been reported from two other sites in Panay: the mountains in San Remegio and Valderrama Municipalities (Antique) and the area spanned by the adjacent towns of Igbaras, Leon, and San Joaquin (Iloilo Province). It was initially assumed that $R$. speciosa was endemic to Panay Island, but photographic evidence (Pastor L. Malabrigo Jr., University of the Philippines, Los Baños, pers. comm.) indicates it also occurs on the lower slopes of Canlaon volcano in Negros. The presence of $R$. speciosa in both Panay and Negros Islands concurs with the Negros-Panay Faunal Region, a large late Pleistocene Island that was formed when the sea level dropped to a maximum of $120 \mathrm{~m}$ below the present level with the development of continental ice sheets (Heaney 1986, Heaney \& Rickart 1990).

Ecology \& Conservation - Rafflesia speciosa grows at $190-800 \mathrm{~m}$ in lowland secondary forest patches on welldrained soils, in gullies, and old reforested, generally dry areas under thick leaf litter. The known populations of $R$. speciosa are vulnerable as their habitat is threatened by slash-and-burn agriculture (Plate 4d). Only the populations in Sibalom and San Remegio Municipalities (Sibalom Natural Park) in Antique, and the population in Negros Island are located in protected areas and the species is categorized as Critically Endangered (DENR-DAO 2007-01).

\section{Rafflesia sp. - Plate 3b}

This species from the Sierra Madre Mountain Range in Luzon (Barcelona et al. 2006, 2007) is described in a separate paper (Barcelona et al. in press). It resembles $R$. tengku-adlinii from Sabah in Borneo in general appearance and floral size and colour. It is, however, different in perigone ornamentation, shape of disk processes, ramenta morphology, length, and disposition, and number of anthers.

Distribution - Luzon. Currently known only from a single locality within the Sierra Madre Mountain Range in Quirino Province.

Ecology \& Conservation - The population occurs at c. $450 \mathrm{~m}$ in a disturbed lowland dipterocarp forest. The flowers form only on the prostrate stems and underground roots and have not been found to grow in the climbing stems of the host. Although small-scale logging and swidden agriculture are prevalent in the area, commercial open-pit mining for gold and copper poses the most serious threat for this Rafflesia habitat. Despite the establishment of the Quirino Protected Landscape, these mining activities continue to seriously jeopardize the survival of this Rafflesia species.

\section{INSUFFICIENTLY KNOWN SPECIES}

\section{A small-flowered Rafflesia species from Mt Matutum, Mindanao}

The finding in the 1980s of Rafflesia buds on the lower slopes of Mt Matutum was first reported by Nais (2001), who suggested that these belong to $R$. schadenbergiana. However, examination in 2002 of material preserved at Central Mindanao University together with an available photograph of the source population composed of senescent flowers and buds (Barcelona et al. 2008b), shows that the collected specimen belongs to a smallflowered Rafflesia species. The material was unfortunately too deteriorated to determine whether or not it represents a new species for the Philippines (Barcelona et al. 2006, 2007).

\section{CONSERVATION STATUS OF PHILIPPINE RAFFLESIA AND THEIR HABITAT}

The lowland tropical rain forest is one of the most threatened forest types in the Philippines and other tropical areas, as listed in World's Biodiversity Hotspots (Mittermeier et al. 1997, Myers et al. 2000). Habitat loss due to logging, mining and the conversion of forest into farmland are among the greatest threats faced by Philippine lowland forests. While the conservation importance of these forests is widely recognized (e.g., Heaney \& Regalado 1998, Mallari et al. 2001, Heaney \& Mallari 2002, Ong et al. 2002), efforts to design effective lowland forest conservation strategies are hampered by a lack of data on their current distribution, the extent to which they have been damaged and destroyed by human impact, and the biodiversity they still contain. Philippine Rafflesia and the bonanza of recent discoveries in this iconic genus highlight how little is known about the biodiversity and ecology of lowland forests and how fragile and endangered the species are that rely on this habitat.

Within a period of about six years, the number of Rafflesia species thought to be present in the Philippines increased nearly fivefold from two species known before 2002 to ten or eleven presently recognized. If these newly discovered members of the genus with the largest flowers of all flowering plants have been overlooked for centuries and, in some cases, even in areas that have been frequently explored by botanists and are among the most popular Philippine tourist destinations (e.g., R. philippensis on Mt Banahaw), what does this tell us about our estimates of the species diversity of organisms in these forests that are much less conspicuous or sought after, such as arthropods or cryptogams? Furthermore, these recent findings indicate how little is known about the ecology of Philippine forests. Rafflesia populations seem to consist of few individuals and are frequently far apart, as is the case for many plant species in tropical rain forests, especially trees. Data on the extent of gene flow between such remote populations is, however, wanting. In addition, hardly anything is known about the distances Rafflesia pollen and seeds travel, and how the seeds are dispersed. In the absence of such information, it is impossible to obtain an accurate estimate of the effects of habitat fragmentation on the survival of Rafflesia, a situation that is relevant to many other inhabitants of lowland forests as well. Rafflesia is also a wonderful example of the intimate way in which many species of the lowland rain forest are dependent upon each other, and also of how poorly studied these interactions are. Because Rafflesia is a holoparasite of the vine Tetrastigma, its fate depends 
entirely on the occurrence and well-being of the host plant in a particular area. We now know that one Tetrastigma species, T. rafflesiae Miq. (syn. T. leucostaphylum (Dennst.) Alston ex Mabb., Veldkamp 2008), is host to at least ten species of Rafflesia, including R. manillana (Nais 2001), and that T. papillosum, cited by Nais (2001) as host to R. pricei and R. kerrii, is also the host of $R$. schadenbergiana. Furthermore, our field observations reveal that at least two species of Tetrastigma are parasitized by $R$. manillana (Plate $1 \mathrm{~d}, \mathrm{f}, \mathrm{g}$ ). As far as is currently known, the remainder of the species of Rafflesia only parasitize one species of Tetrastigma. Notwithstanding these facts, we still know little about host-parasite specificity and to what extent Tetrastigma and Rafflesia are coevolving.

Although the recent discoveries of new species and populations of Philippine Rafflesia have infused the biological community with excitement, especially in the Philippines, these findings also have caused great concern among scientists and environmentalists. All the newly discovered species may be seriously threatened by extinction. Many of them are found in severely degraded forests and are threatened by habitat destruction. In addition to logging and conversion of lowland forest into farmland (Plate $2 \mathrm{~g}, 4 \mathrm{~d}, \mathrm{f}$ ), another, less familiar threat facing Philippine Rafflesia is unsustainable or poorly planned ecotourism. The discovery of new species or populations of Rafflesia is often almost immediately followed by the construction of facilities to attract tourists, such as trails, fences, and viewing platforms; frequently even before conservation action plans can be carried out by the Department of Environment and Natural Resources (DENR). These activities together with clearing of the area and the search for flowers and buds can be detrimental to a Rafflesia population, as we witnessed in Panay, where such activities resulted in the extinction of a population of Rafflesia. On Mt Kitanglad, the population of $R$. schadenbergiana within a parcel of land tilled under a Community Based Forest Management (CBFM) agreement with the DENR (but outside of the buffer zone of the Mt Kitanglad Range Natural Park) is similarly being 'developed' for ecotourism (Plate $4 \mathrm{~g}, \mathrm{~h}$ ). The ecotourism aspect of Rafflesia conservation can be very useful in education and appreciation of our biodiversity (Plate 3o, p), if implemented judiciously. Establishing active Rafflesia sites as ecotourism attractions, therefore, has to be carefully planned and monitored. Ideally, this should remain confined to areas that contain many Rafflesia populations. For ecotourism development to be more meaningful and not detrimental to the plants, consultations with the DENR, local governments, Department of Tourism (DOT), the academic communities, and scientists should be done before opening these Rafflesia sites to the public. Populations that are more accessible could be used for education and ecotourism purposes, whereas those that are in the forest interior and far from human habitation should be pristinely preserved and scientifically studied.

As with most plants and animals in Philippine forests, Rafflesia is currently poorly protected against unsustainable forest use and destruction. Among the Philippine Rafflesia species, only $R$. baletei, $R$. philippensis, $R$. speciosa, a few populations of $R$. manillana, $R$. schadenbergiana, and the only population of Rafflesia sp., are found within protected areas. Currently, of the nine recognized species of Rafflesia in the Philippines, only three, $R$. manillana, $R$. schadenbergiana and $R$. speciosa, are included on the National Red List of Threatened Plants (DENR Administrative Order No. 2007-01). At the time this list was drafted, the other species (R. baletei, R. leonardi, R. lobata, $R$. mira, $R$. philippensis, and the Rafflesia species found in Quirino Province) were not yet formally described or their taxonomic identity was still doubtful. The DAO is amendable every three years and considering the rare and often endangered status of Philippine Rafflesia species, it is strongly recom- mended that they be added to the list in 2010. In addition to pursuing the protection of Rafflesia species and their habitat, cultivation experiments could perhaps help to relieve current active populations from pressure by unsustainable ecotourism. Artificial inoculation of Tetrastigma plants has been successfully done in Java and Malaysia (Nais 2001, Veldkamp 2007) and has helped in boosting both ecotourism and public awareness in the latter country.

\section{REMARKS ON THE CONSERVATION STATUS OF PHILIPPINE LOWLAND FORESTS}

The history of deforestation of the Philippines, between the 1950s until late 1980s, was demonstrated by Kummer (1992) to be a poorly documented and highly politicized phenomenon. Forest cover statistics were plagued by incomplete, conveniently lost or manipulated data, rendering analysis of trends and causes nearly impossible. The forest cover situation of the Philippines during the 1990s to the present, beyond the period covered by Kummer's dissertation, continues to decline, although claims by the Forest Management Bureau (FMB) of the DENR are to the contrary. A much-cited figure of $18.3 \%$ remaining primary and residual forest as of 1999 was made by the Environmental Science for Social Change (ESSC 1999), and depending on the presence or absence of governmental intervention, is estimated to increase to $19 \%$ or further decline to $6.6 \%$ in 2010 , respectively.

One principal gap in all available forest cover data and forest loss projections is the lack of proper classifications of forest types to accompany the statistics; open canopy forest, close canopy forest, production forest, secondary forest, sub-marginal forest, old-growth forest, and other logging terminologies passed on as forest types, continue to be used. Lost in these hazy terminologies and the murky statistics associated with them is the focus on the lowland forest, the most severely threatened forest ecosystem of the Philippines.

As in most tropical regions, the lowland forest is the most utilized resource in the country and has been intensively exploited, resulting in forest fragmentation and massive habitat destruction. Mallari et al. (2001) documented the various threats to most of the remaining forest fragments in the country. For instance, both legal and illegal logging had been conducted and is still ongoing mostly in the dipterocarp forests on larger islands of the country, and to some extent, in forests over limestone (also known as molave forests, e.g. Palawan, Polillo, Samar). Extensive mining and quarrying are conducted in ultramafic forests (e.g., Eastern Mindanao, Palawan, Zambales) and forests over limestone (e.g. Sierra Madre) while conversion to farmlands continues unabated in freshwater swamps and peat swamp forests (e.g., Agusan Marsh, Liguasan Marsh). Few studies of these habitats have been conducted and precious little is known of their current status. At present, with the exception of some data on dipterocarp forests (e.g. Guiang 2001), no available statistics exist on the other lowland forest types with regard to their ongoing exploitation and loss.

The newly described species of Rafflesia and the rediscovered populations of two previously known ones underscore the dilemma of securing the conservation of the lowland biodiversity in the face of continuing degradation and conflicting forestry policies and priorities. All known Rafflesia species in the Philippines occur in forest whose conditions range from regenerating or secondary to severely degraded. Except for a population of $R$. schadenbergiana reported at $1271 \mathrm{~m}$ in South Cotabato and of $R$. manillana at $1200 \mathrm{~m}$ on Mt Irid, all the other species are found below $1000 \mathrm{~m}$ and most are found outside of protected areas. But even within protected areas, conservation of 
Rafflesia is a big challenge. Lowland areas are given very low conservation priority to begin with, and considered of marginal conservation value by previous park planners in the Philippines, resulting in the poor representation of lowland habitats in protected areas of the country, particularly on Luzon and Mindanao (MacKinnon 2002) which, incidentally, are also the islands with the highest diversity of Rafflesia (Map 1). Then, secondary or severely degraded lowland forest within a protected area is typically the core area for multiple-use zone: characterized by extractive activities of tenured migrants, indigenous peoples, and residents of adjacent local communities, or delineated as buffer zone at most. In addition to Rafflesia's poor representation in protected areas, this iconic plant also receives low conservation management priority. Attempts to reduce coverage of protected areas for other landuses sometimes still succeed, such as in the case of Mt Malindang Range Natural Park (Roxas 2005), and will continue to threaten Rafflesia populations even within protected areas. Presently, no data are available regarding management zoning strategies for protected areas where Rafflesia species are found. Thus, we recommend a review of current management zoning criteria to reflect the importance of the lowland forest in the overall strategy to conserve Philippine biodiversity in protected areas. We also recommend further research to document the conservation status of the lowland forest in the Philippines and its associated biodiversity. While an array of conservation interventions have been implemented in the country to ensure the protection of its remarkably unique biodiversity and to arrest the various conservation threats (e.g., Bagadion et al. 2000), none focused specifically on lowland forests.

Acknowledgements We are grateful to the staff of the Department of Environment and Natural Resources (DENR), namely, M.S. Lim, Director Protected Areas and Wildlife Bureau (PAWB), A.C. Manila, Chief, Wildlife Division, PAWB, and staff of the DENR Regional and local offices for facilitating the issuance of collecting and transport permits. We thank the following persons for sharing photographs and information on current distributional ranges: P.L. Malabrigo Jr., E.S. Fernando, I.L. Lit Jr., and M.O. Cajano of the University of the Philippines at Los Baños in Laguna, N.A. Bartolome, Conservation International, Philippines, B. van Ee, Harvard University, D.L. Nickrent, Southern Illinois University, Cagayan Valley Partners in People Development (CAVAPPED) through its President/CEO, P.A. Visorro, A.G. Lenaming and I. Grasparil of The Antique Outdoors (TAO), R.L. Martin Jr., N. Antoque, Tanggol Kalikasan through E.S. Lim Jr., the Candelaria Family, Mayor A.J. Roa of Baungon Bukidnon, Barangay Captain F.C. Babion, and the Antoque and Laque Families. The Field Museum, Chicago, IL through L.R. Heaney provided opportunity for field trips to some of the Rafflesia sites. N.T. Winn (Department of Geography, Miami University) helped us to create the distribution map and J.F. Veldkamp (Nationaal Herbarium Nederland, Leiden) provided copies of the Philippine Rafflesia protologues and suggestions to improve our manuscript. E.J. Tepe (University of Utah) and M. Paz Moreno (University of Cincinnati) translated Blanco's Flora de Filipinas and M.G. Price reviewed the later versions of the manuscript. Finally, we are grateful to Director C.S. Alvina of the National Museum of the Philippines for supporting our research efforts.

\section{REFERENCES}

Anonymous. 1930. 1830-1930 Centennial Memorial Botica Boie, Philippine American Drug Co., Sugar News Press, Manila.

Anonymous. 1992. Small animals help plant a big flower. National Geographic 181 (4).

Bagadion BC, Contreras AP, Leonen MMVF, Malayang BS III, Severino HG, Vitug MD. 2000. Forest policy and politics: The dynamics of participatory Conservation. Ateneo de Manila University Press, Manila.

Bänzinger H. 1991. Stench and fragrance: unique pollination lure of Thailand's largest flower, Rafflesia kerrii Meijer. Natural History Bulletin of the Siam Society 39: 19-52.

Barcelona JF. 2007. Elusive giant flower, Rafflesia schadenbergiana Goeppert, rediscovered? Art I Facts, Official Newsletter of the National Museum of the Philippines, Special Report 9: 7.
Barcelona JF, Cajano MO, Hadsall AS. 2006. Rafflesia baletei, another new Rafflesia (Rafflesiaceae) from the Philippines. Kew Bulletin 61: 231-237. Barcelona JF, Co LL, Balete DS, Bartolome NA. In press. Rafflesia xxx (Rafflesiacea): a new species from Northern Luzon, Philippines. Gardens' Bulletin Singapore 61, 1.

Barcelona JF, Fernando ES. 2002. A new species of Rafflesia (Rafflesiaceae) from Panay Island, Philippines. Kew Bulletin 57: 647-651.

Barcelona JF, Pelser PB, Cabutaje EM, Bartolome NA. 2008a. Another new species of Rafflesia (Rafflesiaceae) from Luzon, Philippines: R. leonardi. Blumea 53: 223-228.

Barcelona JF, Pelser PB, Cajano MO. 2007. Rafflesia banahaw (Rafflesiaceae), a new species from Luzon, Philippines. Blumea 52: 345-350.

Barcelona JF, Pelser PB, Tagtag AM, Dahonog RG, Lilangan AP. 2008b. The rediscovery of Rafflesia schadenbergiana Göpp. ex Hieron. Flora Malesiana Bulletin 14: 162-165.

Beaman RS, Decker PJ, Beaman JH. 1988. Pollination of Rafflesia (Rafflesiaceae). American Journal of Botany 75: 1148-1162.

Blanco FM. 1845. Flora de Filipinas, segun el sistema sexual de Linneo ... ed. 2: 565, 595. M. Sanchez, Manila.

Brown R. 1844. Description of the female flower and fruit of Rafflesia arnoldi, with remarks on its affinities; and an illustration of the structure of Hydnora africana. Transactions of the Linnean Society of London 19: 221-247.

Brown WH. 1912. The relation of Rafflesia manillana to its host. Philippine Journal of Science. Section C, Botany 7: 209-226.

Davis CC, Latvis M, Nickrent DL, Wurdack KJ, Baum DA. 2007. Floral gigantism in Rafflesiaceae. Science 315: 1812.

ESSC. 1999. The decline of the Philippine forest. Ateneo de Manila University, Manila.

Fernando ES, Ong PS. 2005. The genus Rafflesia R.Br. (Rafflesiaceae) in the Philippines. Asia Life Sciences 14: 263-270.

Fernando ES, Sun BY, Suh MH, Kong HY, Soh KS. 2004. Flowering plants and ferns of Mt Makiling. ASEAN-Korea Environmental Cooperation Unit (AKECU), Seoul.

Galang R, Madulid DA. 2006. A second new species of Rafflesia (Rafflesiaceae) from Panay Island, Philippines. Folia Malaysiana 7: 1-8.

Gruèzo WS. 1990. Endangered plants of the Philippines. Life Today 46: 16-18.

Heaney LR. 1986. Biogeography of mammals in Southeast Asia: estimates of rates of colonization, extinction and speciation. Biological Journal of the Linnean Society 28: 127-165.

Heaney LR, Mallari NAD. 2002. A preliminary analysis of current gaps in the protection of threatened Philippine terrestrial mammals. Sylvatrop 10: $28-39$

Heaney LR, Regalado Jr JC. 1998. Vanishing treasures of the Philippine rain forest. The Field Museum, Chicago.

Heaney LR, Rickart EA. 1990. Correlations of clades and clines: Geographic, elevational, and phylogenetic distribution patterns among Philippine mammals. In: Peters G, Hutterer R (eds), Vertebrates in the tropics. Museum Alexander Koenig, Bonn.

Hieronymus G. 1885, '1884'. Ueber Rafflesia schadenbergiana (Göppert). Ein Beitrag zur Kenntnis der Cytinaceen von G. Hieronymus. Breslau. Reprinted in Bull. Internat. Bot. Horticult. St. Petersb. (1884, published 1885) 35-36 and as: Ueber eine neue, von Dr. A. Schadenberg und O. Koch auf Süd-Mindanao entdeckte Art der Gattung Rafflesia. Gartenflora 34 (1885) 3-7, t. 1177.

Kummer DM. 1992. Deforestation in the postwar Philippines. Ateneo de Manila University Press, Manila.

LatiffA, Wong M. 2003. A new species of Rafflesia from Peninsular Malaysia. Folia Malaysiana 4: 135-146.

Lays P. 2006. Rediscovery of a floral jewel in the Philippine archipelago: Rafflesia schadenbergiana Göppert, 1885 (Rafflesiaceae). Lejeunia 182: $1-16$.

Madulid DA. 2000. Philippine plants: endangered plants. Island Publishing House, Manila.

Madulid DA, Agoo EMG. 2008 ('2007'). On the identity of Rafflesia manillana Teschem. (Rafflesiaceae). Philippine Scientist 44: 57-70.

Madulid DA, Buot Jr IE, Agoo EMG. 2008 ('2007'). Rafflesia panchoana (Rafflesiaceae), a new species from Luzon island, Philippines. Acta Manillana 55: 43-47.

Madulid DA, Tandang D, Agoo EMG. 2006 ('2005'). Rafflesia magnifica (Rafflesiaceae), a new species from Mindanao, Philippines. Acta Manillana 53: 1-6.

Madulid DA, Villariba-Tolentino C, Agoo EMG. 2007 ('2006'). Rafflesia banahawensis (Rafflesiaceae), a new species from Luzon, Philippines. Philippine Scientist 43: 43-51.

Mallari NAD, Tabaranza Jr BR, Corsby MJ. 2001. Key conservation sites in the Philippines. Bookmark, Makati City. 
MacKinnon J. 2002. Preliminary analysis of the Philippine protected areas system: gaps and recommendations. In: Ong PS et al. (ed), Philippine biodiversity conservation priorities: A second iteration of the National Biodiversity Strategy and Action Plan: 58-63. Department of Environment and Natural Resources - Protected Areas and Wildlife Bureau, Conservation International Philippines, Biodiversity Conservation Program-University of the Philippines Center for Integrative and Development Studies, and Foundation for Philippine Environment, Quezon City, Philippines.

Meijer W. 1984. New species of Rafflesia. Blumea 30: 209-215.

Meijer W. 1985. Saving the world's largest flower. National Geographic 186 (1): $136-140$.

Meijer W. 1997. Rafflesiaceae. Flora Malesiana, Ser. I, Vol. 13: 1-42.

Merrill ED. 1918. Species Blancoanae: a critical revision of the Philippine species of plants described by Blanco and Llanos. Bureau of Science Publications 12: 1-423.

Merrill ED. 1923. An enumeration of Philippine flowering plants 2. Bureau of Printing, Manila.

Mittermeier RA, Robles Gil P, Mittermeier CG. 1997. Megadiversity: Earth's biologically wealthiest nations. CEMEX, Monterrey, Mexico.

Myers N, Mittermeier RA, Mittermeier CG, Da Fonseca GAB, Kent J. 2000. Hotspots: Earth's biologically richest and most endangered terrestrial ecoregions. Nature 403: 853-858.

Nais J. 2001. Rafflesia of the world. Sabah Parks, Kota Kinabalu.

Ong PS, Afuang LE, Rosell-Ambal RG. 2002. Philippine biodiversity conservation priorities: A second iteration of the National Biodiversity Strategy and Action Plan. Department of Environment and Natural Resources - Protected Areas and Wildlife Bureau, Conservation International Philippines, Biodiversity Conservation Program-University of the Philippines Center for Integrative and Development Studies, and Foundation for Philippine Environment, Quezon City, Philippines.
Philippines Census Office. 1920. Census of the Philippine Islands taken under the direction of the Philippine Legislature in the year 1918 1: Geography, history, and climatology. Bureau of Printing, Manila.

Roxas AT. 2005. Livelihood and extractive activities in Mt Malindang. In: Van der Ploeg J, Masipiquena AB (eds), The future of the Sierra Madre: responding to social and ecological changes. Proceedings of the 5th International Conference on Environment and Development: 245-261. Golden Press, Tugegarao.

Smithsonian Institution. Global Volcanism Program. Volcanic activity report. Volcano names, synonyms, and subfeatures at http://www.volcano.si.edu/ world/allnames.htm.

Susatya A, Arianto W, Mat-Salleh K. 2005. Rafflesia bengkuluensis (Rafflesiaceae), a new species from south Sumatera, Indonesia. Folia Malaysiana 6: 139-152.

Tan BC, Fernando ES, Rojo JP. 1986. An updated list of endangered Philippine plants. Yushania 3: 1-5.

Teschemacher JE. 1842. On a new species of Rafflesia, from Manila. Boston Journal of Natural History 4:63-66, t. 6. Reprinted in Annals and Magazine of Natural History, including Zoology, Botany, and Geology 9, 59 (July 1842) 381-384, t. 5 (IDC microfiche).

Veldkamp JF. 2007. Some notes on the cultivation of Rafflesia. Flora Malesiana Bulletin 14: 50-53.

Veldkamp JF. 2008. The correct name for the Tetrastigma (Vitaceae) host of Rafflesia (Rafflesiaceae) in Malesia and a (not so) new species. Reinwardtia 12: 261-265. 